This item was submitted to Loughborough's Research Repository by the author.

Items in Figshare are protected by copyright, with all rights reserved, unless otherwise indicated.

\title{
The effect of dietary (poly)phenols on exercise-induced physiological adaptations: a systematic review and meta-analysis of human intervention trials
}

\section{PLEASE CITE THE PUBLISHED VERSION}

https://doi.org/10.1080/10408398.2020.1860898

\section{PUBLISHER}

Taylor \& Francis

\section{VERSION}

AM (Accepted Manuscript)

\section{PUBLISHER STATEMENT}

This is an Accepted Manuscript of an article published by Taylor \& Francis in Critical Reviews in Food Science and Nutrition on 24 December 2020, available online:

http://www.tandfonline.com/10.1080/10408398.2020.1860898.

\section{LICENCE}

CC BY-NC-ND 4.0

\section{REPOSITORY RECORD}

Martinez-Negrin, Guille, Jarred Acton, Stuart Cocksedge, Stephen Bailey, and Tom Clifford. 2020. "The Effect of Dietary (poly)phenols on Exercise-induced Physiological Adaptations: A Systematic Review and Metaanalysis of Human Intervention Trials". Loughborough University. https://hdl.handle.net/2134/13514870.v1. 
1 Title: The effect of dietary (poly)phenols on exercise-induced physiological adaptations: a

2 systematic review and meta-analysis of human intervention trials

3 Authors: Guille Martinez-Negrin ${ }^{1}$, Jarred P. Acton ${ }^{1}$, Stuart P. Cocksedge ${ }^{1}$, Stephen J. Bailey ${ }^{1}$, 4 Tom Clifford $^{1 *}$

$5{ }^{1}$ School of Sport, Exercise and Health Sciences, Loughborough University, Loughborough, 6 UK, LE11 3TU.

7

8 *Corresponding author: Tom Clifford, School of Sport, Exercise and Health Sciences, 9 Loughborough University, Loughborough, UK, LE11 3TU. Email: t.clifford@lboro.ac.uk.

Keywords: Phytochemicals; phenols; antioxidants; oxidative stress; redox balance; nutrition. 


\section{Abstract}

We performed a systematic review and meta-analysis to determine whether (poly)phenol supplementation augments the physiological adaptations to exercise training. Eligible studies administered a (poly)phenol supplement alongside $\geq 2$ weeks of supervised exercise in adult humans. After screening, 22 studies were included in the analysis. Isoflavones and green tea (poly)phenols were administered most frequently. Quality assessments suggested most studies were free from bias. (Poly)phenols had no effect on training-induced adaptations in muscle strength, peak power output, and $\dot{V} \mathrm{O}_{2 \max }$, but enhanced exercise capacity (SMD: $0.67,95 \% \mathrm{CI}$ : 0.25 to $1.09, \mathrm{P}<0.01$ ). (Poly)phenols had no overall effect on fat loss (SMD: $0.10,95 \% \mathrm{CI}$ : 0.10 to $0.29 ; \mathrm{P}=0.97$ ) or lean mass gains (SMD: $0.06,95 \% \mathrm{CI}:-0.18$ to $0.30, \mathrm{P}=0.62$ ) but sub-analysis suggested that isoflavones increased lean mass (SMD: 0.25, $95 \mathrm{CI} \%:-0.00$ to 0.50, $\mathrm{P}=0.05)$. Resveratrol impaired adaptations in two studies, although this was a non-statistically significant finding (SMD: $-0.54,95 \% \mathrm{CI}:-1.15$ to $0.07, \mathrm{P}=0.08$ ). Our results suggest that isoflavones may augment aspects of the adaptive response to exercise training, while resveratrol may compromise training adaptations. More high-quality research is needed to resolve the effects of (poly)phenols on exercise training adaptations. 


\section{Introduction}

(Poly)phenols are chemical compounds found in plants and some animal foods (Frank et al. 2019). Structurally, they contain one or more phenolic rings attached to a hydroxyl group (Frank et al. 2019; Bravo 2009). More than 8,000 distinct (poly)phenol structures have been identified and they are typically classified into four major families: lignans, stilbenes, phenolic acids, and flavonoids (Bravo 2009; Crozier et al. 2007). They are particularly abundant in fruits, vegetables, coffee, tea, cocoa, herbs, and spices (Scalbert et al. 2002). A high intake of these (poly)phenol-rich foods is associated with a reduced risk of chronic diseases, including several cancers, cardiovascular disease, and diabetes (Wedick et al. 2012; Knekt et al. 2002; Arts and Hollman 2005). These findings have been ascribed to a myriad of putative physiochemical effects, including antioxidant, anti-inflammatory, anti-atherogenic, anticarcinogenic, anti-microbial, vasodilation, and chemoprotection, conferred by (poly)phenolrich foods (Pandey and Rizvi 2009).

There is a growing interest in whether (poly)phenol supplements can augment adaptations evoked by exercise training, such as increased aerobic capacity and muscle strength (Costa et al. 2017; Layne et al. 2017; Gaamouri et al. 2019). These physiological adaptations are not only important for sports performance but also general health. Indeed, low fitness is associated with an increased risk of mortality (Sui et al. 2007; Gander et al. 2011), and a progressive loss in muscle strength is a hallmark of sarcopenia, a condition affecting $\sim 10 \%$ of the global population (Shafiee et al. 2017). Therefore, strategies with the potential to boost exerciseinduced adaptations are of great interest to athletes and healthcare practitioners.

Several mechanisms have been proposed to explain how (poly)phenols might augment exercise-induced physiological adaptations; enhanced muscle blood flow (and therefore $\mathrm{O}_{2}$ delivery during exercise), which may enable greater intensity training to be completed 
69

(Morgan, Barton, and Bowtell 2019; Trexler et al. 2014); enhanced mitochondrial biogenesis, resulting from stimulation of key signalling cascades such as peroxisome proliferator-activated receptor coactivator 1 alpha (PGC1- $\alpha$ ) (Sandoval-Acuña, Ferreira, and Speisky 2014; Davis et al. 2009a); upregulated antioxidant defence, via stimulation of nuclear factor erythroid 2related factor 2 (Nrf2), which regulates the transcription of several antioxidant genes (Christensen and Christensen 2013; Mi et al. 2018) and; accelerated between-workout recovery, owing to a decrease in inflammation and oxidative stress (Doma, Gahreman, and Connor 2020; Wiswedel et al. 2004). Most of these effects are ascribed to the vasodilatory, antioxidant and anti-inflammatory effects of (poly)phenols, which are well-established in vitro (Rice-Evans, Miller, and Paganga 1997; Scalbert, Johnson, and Saltmarsh 2005) but more equivocal in humans (Forman, Davies, and Ursini 2014; Hollman et al. 2011). Pre-clinical studies also suggested that some (poly)phenols, notably catechins from green tea or cocoa, may also exert thermogenic effects by decreasing catechol-O-methyltransferase (COMT), an enzyme that inhibits norepinephrine and $\beta$-oxidation (Dos Santos et al. 2018; Lin and LinShiau 2006a). Thus, (poly)phenols may work synergistically with exercise to assist with weight management.

To date, clinical trials combining exercise training and (poly)phenol supplementation have produced equivocal findings. For example, a recent study found that carob (poly)phenols (208 $\mathrm{mg} \cdot$ day $^{-1}$ ) alongside 6 weeks of taekwondo training increased distance ran during an intermittent shuttle running test (Gaamouri et al. 2019). By contrast, green tea (poly)phenols $\left(573 \mathrm{mg} \cdot\right.$ day $\left.^{-1}\right)$ combined with 60 min of cycling 3 days $^{\cdot}$ week $^{-1}$ for 10 weeks did not augment maximal aerobic capacity $\left(\dot{V} \mathrm{O}_{2 \max }\right)$ compared to a placebo in heathy young males (Ichinose et al. 2011). Other studies combining (poly)phenol supplementation and exercise training reported that physiological adaptations were enhanced (Thompson et al. 2018) or unchanged (Sadowska-Krępa et al. 2019; Kuo et al. 2015). In addition, some studies have observed 
augmented body fat losses when (poly)phenols are consumed alongside an exercise program (Aubertin-Leheudre et al. 2007; Lebon et al. 2014) while others have not (Hill et al. 2007; Choquette et al. 2011).

In contrast to studies reporting positive or no effects of (poly)phenol supplementation on exercise training adaptations, a few studies have observed that (poly)phenol supplementation inhibits some exercise-induced physiological adaptations (Schwarz et al. 2018; Scribbans et al. 2014). The antagonistic effects of (poly)phenol supplements on exercise adaptations has been attributed to their antioxidant and/or anti-inflammatory properties (Schwarz et al. 2018; Scribbans et al. 2014). Exercise generates reactive oxygen and nitrogen species that act as signalling molecules for physiological adaptations, and curbing them with nutritional antioxidants like vitamin $\mathrm{C}$ and $\mathrm{E}$ has been shown to blunt adaptations in some (GomezCabrera et al. 2008; Paulsen et al. 2014) but not all studies (Yfanti et al. 2011; Roberts et al. 2011). However, most (poly)phenols have poor bioavailability (Halliwell 2008) and are not present in the same concentrations as vitamin $\mathrm{C}$ and $\mathrm{E}$ when consumed orally. For example, (poly)phenol doses of $1000 \mathrm{mg}$ or more may only lead to maximum systemic concentrations of $\sim 7 \mu \mathrm{M}$ (Habauzit and Morand 2012; Manach et al. 2005), whereas $1000 \mathrm{mg}$ of vitamin $\mathrm{C}$ or $440 \mathrm{mg}$ of vitamin E, doses typically given in intervention studies, can lead to plasma concentrations of $\geq 70 \mu \mathrm{M}$ (Dimitrov et al. 1991; Close et al. 2006). As such, their in vivo mechanisms of action are likely distinct to antioxidant vitamins and other anti-oxidants (e.g., $\mathrm{n}$-acetyl cysteine); indeed, the current consensus is that at most (poly)phenols only have indirect antioxidant effects (instead of direct scavenger effects) via the stimulation of Nrf2, which is widely regarded as a desirable response (Ursini, Maiorino, and Forman 2016; Cuadrado et al. 2018). Whether (poly)phenols are beneficial or harmful during exercise training may depend on the type of exercise training intervention; the duration, dose, and type of (poly)phenols consumed; habitual (poly)phenol intake, baseline concentrations of 
119 (poly)phenols, and redox status (Margaritelis et al. 2020); and the age and sex of the participants. However, the influence of these variables has not yet been systematically investigated.

The equivocal findings in individual studies means there is little consensus as to whether (poly)phenols augment, blunt or have no effects on exercise-induced physiological adaptations.

This has important implications for applied practitioners who recommend (poly)phenols to clients, and athlete and patient populations who self-administer (poly)phenols as adjuvant therapies during exercise. Therefore, this study conducted a systematic review and metaanalysis of studies examining the combined effects of (poly)phenol supplementation during exercise-training on physiological adaptations (changes in performance and body composition) in humans, as compared to an exercise only or exercise plus placebo group.

\section{Methods}

\section{Search Strategy}

The protocol was pre-registered on the International Prospective Register of Systematic Reviews (PROSPERO) database (registration number: CRD201532) and is reported according to the Preferred Reporting Items for Systematic Reviews and Meta-Analyses (PRISMA) guidelines (Moher et al. 2009). English language articles from Medline and SPORTDiscus databases were searched from inception to June 20th, 2020. Our search strategy was based on our Population Intervention Comparator Outcome and Study Design (PICOS) framework (Online Supplementary Material). We used Boolean operators, as well as truncation "*” and wildcard "\#" terms where appropriate to increase the sensitivity of the search. The full search strategy is available in the Online Supplementary Material. Titles and abstracts were screened for eligibility by two independent reviewers (GMN and TC). The full texts of any articles deemed eligible at this stage were retrieved and checked for inclusion by both authors. The 
reference list of eligible studies and relevant review articles were screened for additional articles. Both reviewers agreed on the full texts included in the review. Figure 1 provides a flow diagram of the search strategy.

\section{Inclusion criteria}

Inclusion criteria were: 1 ) adult participants $\geq 18$ years; 2) studies examining the combined effects of (poly)phenol supplement(s) and a supervised exercise training program of $\geq 2$ weeks duration; 3) a comparator group performing the same exercise training program but receiving either an inert placebo supplement or no supplement (i.e., exercise-only group); 4) studies reporting changes in body composition, aerobic/exercise capacity or muscle strength performance; 5) randomized, parallel design, controlled trials in humans. Studies with non(poly)phenol supplements or that provided insufficient information on the supplementation regimen or exercise program were excluded.

\section{Data Extraction}

Type, age and number of participants, interventions and comparators, exercise program, and mean \pm SD for each outcome, were extracted into a Microsoft Excel Spreadsheet. If the standard error of the mean (SEM) was provided, SD was calculated with the following formula: $\mathrm{SD}=$ sqrt $(\mathrm{n}) \times \mathrm{SEM}$, whereby $\mathrm{n}$ is the number of subjects (Higgins, Thomas , Chandler, Cumpston, Li, Page 2019). For one study (Barsalani et al. 2013), SD were calculated from confidence intervals with the following formula taken from Chapter 6 of the Cochrane Handbook (Higgins, Thomas, Chandler, Cumpston, Li, Page 2019): SD = sqrt $(\mathrm{n}) \times($ upper limit - lower limit) $/ X$, where $X$ is a divisor generated from a t distribution. Data not available in the text was obtained from authors $(n=1)$ or using online software (WebPlotDigitizer, Version 3.12) $(\mathrm{n}=2)$. 


\section{Heterogeneity, Risk of Bias, and Sensitivity Analyses}

Heterogeneity was assessed via Chi-square $\left(\mathrm{Chi}^{2}\right)$ and $\mathrm{I}^{2}$ statistics. $\mathrm{A} \mathrm{Chi}{ }^{2}$ test of $\mathrm{P}>0.10$ indicated significant heterogeneity. An $\mathrm{I}^{2}$ of $<25 \%$ was considered low risk; $25-75 \%$ moderate risk; $>75 \%$ high risk (Higgins et al. 2003). The quality of evidence was assessed with the Cochrane risk of bias tool (Higgins 2011). This was conducted independently by two investigators (GMN and JA) and any disagreement resolved by a third investigator (TC). Three separate sensitivity analyses were performed to assess their influence on the meta-analysis: we removed studies with a high risk of bias, that reported mean changes from baseline values, and that contained no placebo control group.

\section{Outcome Categorization and Subgroup Analyses}

We performed separate analysis on upper-body and lower-body strength measures. Exercise performance measures were categorized as peak power output, exercise capacity (time to exhaustion or total distance covered) or timed up and go test. Some studies included several measures of body composition and maximal aerobic capacity. To avoid within-study effect size multiplicity (López-López et al. 2018), we selected one outcome per study for our metaanalysis using a decision rule. If multiple instruments were used to measure the same outcome (e.g., body fat) we selected the most relevant effect size according to a pre-defined hierarchy (see Table S2 for full list) (Bidonde et al. 2017; López-López et al. 2018). Briefly, for body composition, we preferentially extracted whole body measures; for $\dot{V} \mathrm{O}_{2 \max }$, we preferentially selected relative values; for muscle strength, we preferentially extracted isometric and dynamic strength tests. Markers of exercise performance were considered independently. When sufficient studies permitted ( $\geq 2$ measuring the same outcome), we performed sub-group analysis for age and supplement type (both were pre-specified). Older adults were classified as 
190

191

192

193

194

195

196

197

198

199

200

201

202

203

204

205

206

207

208

209

210

211

212

$\geq 50$ years, as this is when physiological decline is proposed to accelerate (Borges et al. 2016; Clifford 2019).

\section{Statistical Analyses}

Review Manager 5.4 was used to perform the meta-analysis (Cochrane Collaboration, UK).

Standardized mean differences (SMDs) were calculated for outcome measures as they were not taken on the same scale. Random effects models were used to account for the heterogeneous study designs. Funnel plots were performed to evaluate publication bias for studies measuring body composition changes (Figure S1). Funnel plots were not calculated for other variables as they contained less than 10 studies and thus the finding may not be valid (Higgins 2011).

\section{Results}

\section{Search Results}

Our search strategy retrieved 1,840 studies, which was reduced to 1,644 after removing duplicates (Figure 1). After screening the title and abstracts, 38 full-text articles were identified for further assessment. A further 7 papers were identified for assessment from the reference lists of relevant review articles (Bowtell and Kelly 2019; Myburgh 2014; Somerville, Bringans, and Braakhuis 2017). After screening the full-texts, 23 studies were excluded (see Figure 1 and Table S3), leaving 22 studies for inclusion in the final meta-analysis.

\section{Study Characteristics}

Table 1 and Table 2 summarize studies assessing the effects of (poly)phenols on exercise induced changes in body composition and performance $(\mathrm{n}=16)$ and performance and strength $(n=6)$, respectively. Six studies measured body composition and performance (Barbosa et al. 2019; Gaamouri et al. 2019; Gliemann et al. 2013; Orsatti et al. 2010; Kim et al. 2013; Mafi et al. 2019). All studies employed a parallel study design with the intervention and control groups 
completing an exercise training program equal in duration to the supplementation period. In three studies, the control group performed the same exercise program but were not provided with a placebo supplement (Mafi et al. 2019; Amozadeh, Shabani, and Nazari 2018; Kim et al. 2013). Furthermore, the control group for one study (Thompson et al. 2018) provided potassium nitrate and although this is not an inert placebo, this group was used as the control since potassium nitrate does not contain (poly)phenol compounds. The interventions ranged from 4 weeks to 12 months, with the average duration being 13 weeks. Only four studies were longer than 13 weeks (Barsalani et al. 2013; Choquette et al. 2011; Lebon et al. 2014; Orsatti et al. 2010).

A total of 646 participants were included in the meta-analysis; 453 were females and 174 males. This is excluding participants from one study who recruited female and male participants but did not specify the numbers of each sex (Schwarz et al. 2018). More than half of the studies (n $=12)$ recruited adults $\geq 50$ years old $(n=444)$ (Aubertin-Leheudre et al. 2007; Barbosa et al. 2019; Barsalani et al. 2013; Choquette et al. 2011; Gliemann et al. 2013; Lebon et al. 2014; Mafi et al. 2019; Orsatti et al. 2010; Hill et al. 2007; Kim et al. 2013; Wu, Oka, Higuchi, et al. 2006; Giolo et al. 2018). Some participants were classified as obese or overweight $(n=276)$ (Hill et al. 2007; Bagheri et al. 2020; Amozadeh, Shabani, and Nazari 2018). Others recruited overweight postmenopausal females $(n=162)$ (Aubertin-Leheudre et al. 2007; Barsalani et al. 2013; Choquette et al. 2011; Lebon et al. 2014; Orsatti et al. 2010); healthy postmenopausal females $(\mathrm{n}=124)$ (Barbosa et al. 2019; Wu, Oka, Higuchi, et al. 2006; Giolo et al. 2018); healthy and recreationally active adults $(n=67)$ (Ichinose et al. 2011; Schwarz et al. 2018; Thompson et al. 2018; Sadowska-Krępa et al. 2019); healthy but non-active adults $(\mathrm{n}=63)$ (Gliemann et al. 2013; Scribbans et al. 2014; Kuo et al. 2015); sarcopenic adults ( $\mathrm{n}=93$ ) (Kim et al. 2013; Mafi et al. 2019); and national-level athletes $(\mathrm{n}=20)$ (Gaamouri et al. 2019). 
Five different (poly)phenol supplements were assessed: isoflavones (Aubertin-Leheudre et al. 2007; Barbosa et al. 2019; Barsalani et al. 2013; Choquette et al. 2011; Giolo et al. 2018; Lebon et al. 2014; Orsatti et al. 2010; Wu, Oka, Tabata, et al. 2006); (poly)phenols derived from tea, including green tea, green tea extract, tea catechin and epigallocatechin gallate (Amozadeh, Shabani, and Nazari 2018; Bagheri et al. 2020; Hill et al. 2007; Ichinose et al. 2011; SadowskaKrępa et al. 2019; Kim et al. 2013; Kuo et al. 2015); resveratrol (Gliemann et al. 2013; Scribbans et al. 2014); epicatechin (Mafi et al. 2019; Schwarz et al. 2018); carob extract (Gaamouri et al. 2019) and beetroot juice (Thompson et al. 2018). The exercise programme implemented alongside the supplement intervention varied widely: aerobic exercise (AubertinLeheudre et al. 2007; Amozadeh, Shabani, and Nazari 2018; Bagheri et al. 2020; Hill et al. 2007; Ichinose et al. 2011; Kuo et al. 2015; Schwarz et al. 2018; Wu, Oka, Higuchi, et al. 2006), resistance training (Orsatti et al. 2010; Mafi et al. 2019; Kim et al. 2013); a combination of resistance and aerobic training (Barbosa et al. 2019; Barsalani et al. 2013; Choquette et al. 2011; Giolo et al. 2018; Lebon et al. 2014; Gliemann et al. 2013); sprint interval training (Scribbans et al. 2014; Thompson et al. 2018); sport-specific training (Gaamouri et al. 2019; Sadowska-Krępa et al. 2019).

\section{Risk of Bias}

The quality of evidence was generally high but only three studies had a low risk of bias for all outcomes (Figure 2 and Figure S2). Allocation concealment had an unclear risk of bias in several studies due to insufficient information regarding the concealment protocol (Bagheri et al. 2020; Choquette et al. 2011; Gaamouri et al. 2019; Giolo et al. 2018; Gliemann et al. 2013; Hill et al. 2007; Ichinose et al. 2011; Mafi et al. 2019; Sadowska-Krępa et al. 2019; Schwarz et al. 2018; Scribbans et al. 2014; Kuo et al. 2015; Wu, Oka, Higuchi, et al. 2006). Three studies were considered to have an unclear risk of bias for allocation concealment since the control group did not consume a placebo, only performing exercise (Kim et al. 2013; Amozadeh, 
Shabani, and Nazari 2018; Mafi et al. 2019). Only one study was considered to have an unclear risk of bias for random sequence generation and high risk for selective reporting (Gliemann et al. 2013). With regards to performance and detection bias, two studies were considered to have a high risk of bias for both outcomes since supplementation was not double-blinded (Amozadeh, Shabani, and Nazari 2018; Sadowska-Krępa et al. 2019). Three studies had an unclear risk of attrition bias as reasons for participant withdrawals were not provided (Barsalani et al. 2013; Gaamouri et al. 2019; Sadowska-Krępa et al. 2019). For "other" bias, four studies were deemed to have an unclear risk of bias as they were funded by a pharmaceutical company and it was unclear what involvement they had on the study design (Aubertin-Leheudre et al. 2007; Hill et al. 2007; Lebon et al. 2014; Orsatti et al. 2010).

The funnel plots for body fat and lean mass gains are symmetrical suggesting minimal evidence for publication bias (Figure S2).

\section{Meta-analysis results}

\section{Exercise performance}

(Poly)phenols had no effect on training-induced changes in peak power output (SMD: -0.04, 95\% CI: -0.57 to $0.49, \mathrm{P}=0.89 ; \mathrm{Chi}^{2}=0.15, \mathrm{I}^{2}=0 \%, \mathrm{P}=0.93$ ) or timed up and go test (SMD: $0.24,95 \% \mathrm{CI}:-0.17$ to $0.64, \mathrm{P}=0.26 ; \mathrm{Chi}^{2}=0.53 ; \mathrm{I}^{2}=0 \%, \mathrm{P}=0.93$ ) (Figure $3 \mathrm{~A}$ and $\mathrm{C}$, respectively) but enhanced exercise capacity (SMD: 0.67, 95\% CI: 0.25 to $1.09, \mathrm{P}<0.01$ Chi $^{2}$ $\left.=0.35, \mathrm{I}^{2}=0 \%, \mathrm{P}=0.95\right)$ (Figure $3 \mathrm{~B}$ ). Subgroup analyses were not performed due to limited studies measuring these outcomes.

\section{Muscle strength}

(Poly)phenols did not alter training-induced adaptations in upper-body strength (SMD: 0.00, 95\% CI: -0.41 to $0.40, \mathrm{P}=0.99 ; \mathrm{Chi}^{2}=0.02, \mathrm{I}^{2}=0 \%, \mathrm{P}=0.90$ ) (Figure 3E). No subgroup analyses were conducted as only two studies were included in the main analysis. Similar 
findings were observed with lower-body strength (SMD: $-0.03,95 \% \mathrm{CI}$ : -0.35 to $0.28, \mathrm{P}=$ $0.85 ; \mathrm{Chi}^{2}=1.35, \mathrm{I}^{2}=0 \%, \mathrm{P}=0.72$ ) (Figure 3D). Subgroup analysis on isoflavone supplementation showed no significant effect on lower-body strength compared to a CON (SMD: $-0.09,95 \% \mathrm{CI}:-0.65$ to $0.47, \mathrm{P}=0.74$ Chi $\left.^{2}=1.26, \mathrm{I}^{2}=21 \%, \mathrm{P}=0.26\right)$ (Figure S3).

\section{$\dot{V} O_{2 \max }$}

(Poly)phenols had no effect on training-induced changes in $\dot{V} \mathrm{O}_{2 \max }$ (SMD: $-0.12,95 \% \mathrm{CI}$ : 0.47 to $0.23, \mathrm{P}=0.89 ; \mathrm{Chi}^{2}=4.24, \mathrm{I}^{2}=0 \%, \mathrm{P}=0.93$ ) (Figure $4 \mathrm{~A}$ ). In our sub-group analysis, resveratrol (SMD: $-0.54,95 \% \mathrm{CI}:-1.15$ to $0.07, \mathrm{P}=0.08 ; \mathrm{I}^{2}=0 \%, \mathrm{P}=0.64$ ) (Figure $4 \mathrm{~B}$ ) and tea-derived (poly)phenols did not augment $\dot{V} \mathrm{O}_{2 \max }$ (SMD: $0.25,95 \% \mathrm{CI}$ : -0.32 to $0.82, \mathrm{P}=$ 0.39; $\mathrm{Chi}^{2}=0.09, \mathrm{I}^{2}=0 \%, \mathrm{P}=0.96$ ) (Figure 4B). Only one study (Gliemann et al. 2013) measured changes in $\dot{V} \mathrm{O}_{2 \max }$ in older adults; a sub-group analysis in younger adults showed no effect of (poly)phenols (Figure S4).

\section{Body fat}

(Poly)phenols did not augment exercise-induced changes in body fat losses (SMD: 0.10, 95\% CI: -0.10 to $0.29, \mathrm{P}=0.32 ; \mathrm{Chi}^{2}=4.67, \mathrm{I}^{2}=0 \%, \mathrm{P}=0.97$ ) (Figure $5 \mathrm{~A}$ ). Sub-group analysis revealed no differences in younger or older adults (SMD: $0.10,95 \% \mathrm{CI}:-0.12$ to $0.32, \mathrm{P}=0.37$; $\mathrm{Chi}^{2}=3.68, \mathrm{I}^{2}=0 \%, \mathrm{P}=0.89$ ) (Figure 5B). Similarly, subgroup analyses in isoflavone (SMD: 0.04, 95\% CI: -0.21 to $\left.0.28, \mathrm{P}=0.77 ; \mathrm{Chi}^{2}=1.76, \mathrm{I}^{2}=0 \%, \mathrm{P}=0.94\right)$ and tea-derived (poly)phenols (SMD: $0.29,95 \% \mathrm{CI}:-0.08$ to $0.66, \mathrm{P}=0.12 ; \mathrm{Chi}^{2}=1.03 ; \mathrm{I}^{2}=0 \%, \mathrm{P}=0.79$ ) showed no benefits compared to a placebo (Figure 5C).

(Poly)phenols showed no effect on changes in lean body mass (SMD: 0.06, 95\% CI: -0.18 to $0.30, \mathrm{P}=0.62 ; \mathrm{Chi}^{2}=14.73, \mathrm{I}^{2}=32 \%, \mathrm{P}=0.14$ ) (Figure $\left.6 \mathrm{~A}\right)$. Isoflavone supplementation appeared to augment lean mass gains (SMD: 0.25, $95 \mathrm{CI} \%$ : -0.00 to $0.50, \mathrm{P}=0.05 ; \mathrm{Chi}^{2}=4.91$, $\mathrm{I}^{2}=0 \%, \mathrm{P}=0.56$ ) but tea-derived (poly)phenols had no effect (SMD: $-0.25,95 \% \mathrm{CI}:-0.64$ to 
$0.14, \mathrm{P}=0.21, \mathrm{Chi}^{2}=0.09, \mathrm{I}^{2}=0 \%, \mathrm{P}=0.77$ ) (Figure $6 \mathrm{~B}$ ). All studies were conducted in older adults.

312 Although not pre-specified, as there was sufficient studies we also performed a sub-group analysis to explore the influence of training type (aerobic training, resistance training, or a mixture of aerobic training and resistance training) on changes on lean mass and body fat with (poly)phenol supplementation. However, this analysis did not yield any significant influence of training mode on these outcome measures (data not shown; all $\mathrm{P}>0.05$ ).

\section{Sensitivity Analyses}

Sensitivity analyses (data not shown), in which studies were removed when they did not provide an inert placebo to the control group (i.e., an exercise-only group) or had a high risk of bias, and/or provided data as mean changes from baseline, did not significantly alter the pooled results for lower- body strength $\left(\mathrm{n}=2\right.$ removed), $\dot{V} \mathrm{O}_{2 \max }(\mathrm{n}=1$ removed), body fat (n $=3$ removed $)$ and lean body mass $(\mathrm{n}=4$ removed $)$.

\section{Discussion}

The main findings of the present systematic review and meta-analysis are: 1) (poly)phenols do not modulate training-induced improvements in $\dot{V} \mathrm{O}_{2 \max }$, peak power output, or muscle strength, but may augment exercise capacity; 2) (poly)phenols do not stimulate greater body fat losses, but isoflavones may enhance lean mass gains; and 3) resveratrol may blunt aerobic exercise-induced adaptations. Only 5 types of (poly)phenols were examined in the eligible studies, though most were with isoflavones or derived from green tea. Overall, our analysis included a limited number of studies with small sample sizes, making it difficult to draw definitive conclusions about the efficacy of (polyp)phenols for stimulating exercise-induced fat loss or physiological adaptations. 
The most frequently measured outcome was changes in body composition, either as fat mass losses or lean mass gains. Our pooled analysis suggests (poly)phenols, predominantly isoflavones and green tea extracts, were no better than a placebo for altering body fat or lean mass when combined with exercise. This suggests any effects these (poly)phenols may have on thermogenesis (Lin and Lin-Shiau 2006b; Dos Santos et al. 2018) do not translate to greater fat losses during an exercise training program. In contrast, our sub-group analysis suggested isoflavones augmented lean mass gains when taken alongside exercise-training, albeit with a small effect (SMD: 0.25). It is unclear why isoflavones seemed to augment lean mass gains, but the tea-derived (poly)phenols in our other sub-group analysis did not. It could be because there were more studies using isoflavone supplementation and this gave us greater statistical power to detect effects. It is also possible that health status influenced these results; the studies with isoflavone supplementation were all in post-menopausal females. The length of the intervention could have also influenced the results; those with isoflavones tended to be of longer duration ( $\geq 6$ months) than the studies in tea (poly)phenols ( 3 months). It might be that a longer training and supplementation period is required to achieve meaningful changes. It is also possible that isoflavones are simply more potent than tea derived (poly)phenols due to their comparatively superior bioavailability, irrespective of dose (Del Rio et al. 2013). Future studies are required to explore the effects of combing isoflavones and exercise-training in other populations.

Akin to studies with the nutritional antioxidants vitamin C and E (Gøran Paulsen et al. 2014; Gomez-Cabrera et al. 2008), there was evidence from individual studies that (poly)phenols blunted exercise-induced improvements in $\dot{V} \mathrm{O}_{2 \max / \text { peak }}$ (Gliemann et al. 2013; Scribbans et al. 2014; Schwarz et al. 2018). Two of these studies administered resveratrol, a stilbenoid found in red wine that has gained attention as an exercise mimetic (Momken et al. 2011; Guerrieri, Moon, and van Praag 2017). In a sub-group analysis, resveratrol had a moderate (SMD: 0.54), 
albeit non-significant, antagonistic effect on exercise-induced changes in $\dot{V} \mathrm{O}_{2 \text { max }}$. The attenuation in $\dot{V} \mathrm{O}_{2 \max }$ gains in these studies contrasts with animal data, which consistently shows resveratrol augments physiological adaptations associated with exercise (Dolinsky et al. 2012; Lagouge et al. 2006; Hart et al. 2013). The mechanisms by which resveratrol blocks these adaptations in humans is not well-understood. One study suggested that resveratrol may have blunted redox signalling in skeletal muscle, although they did not measure any reactive species or redox changes to confirm this postulate (Gliemann et al. 2013). Scribbans et al. (2013) found that resveratrol blunted the increase in PGC1- $\alpha$ and Sirtuin 1 expression, which could partly explain how resveratrol compromised improvements in $\dot{V} \mathrm{O}_{2 \max }$. Future studies are needed to confirm these findings and determine how resveratrol and other (poly)phenols may disrupt reactive species mediated signalling, and other putative signalling responses, to hinder exercise-induced physiological adaptations.

There was no effect of (poly)phenols on exercise-induced changes in $\dot{V} \mathrm{O}_{2 \max }$, muscle strength, peak power output or timed-up and go test, but a small improvement in exercise performance, as measured by time-to exhaustion and time trial tests, was observed. The studies measuring exercise capacity all used a different (poly)phenol (Table 2), so these results are unlikely related to the type of supplement consumed. Mechanisms to explain these effects are unclear, but combining (poly)phenols with exercise-training has been shown to enhance mitochondrial biogenesis and antioxidant responses, at least in animal models (Davis et al. 2009b; Bruns et al. 2018; Sahin et al. 2016). Assuming these changes are reproducible in humans, this could account for enhanced exercise performance after exercise training with concomitant (poly)phenol supplementation. While these findings are promising and warrant further investigation, they should be interpreted cautiously as only 4 studies were included in the analysis and the effect size was moderate (SMD: 0.67). 
Ageing is associated with progressive disruption to immune function, redox balance, and protein signalling, all of which attenuate the ability to adapt to an acute stress, such as exercise (Done et al. 2016). As such, older adults may not receive the same physiological benefits from exercise as their younger counterparts. Although not a consistent finding, studies have found re-establishing immune function and redox balance with anti-inflammatory drugs or nutritional antioxidants may augment exercise-induced adaptations in older adults, while having deleterious effects in healthy younger adults (Trappe et al. 2016; 2011; Gomez-Cabrera et al. 2013). Analogously, (poly)phenols may also preferentially benefit older adults, although this has received less attention in the literature. Although the present study intended to assess the potential for an age dependence of (poly)phenol supplementation during training by performing a sub-group analysis of older and younger adults for each outcome, there was only sufficient data to analyse age-related differences for body fat losses, and there was no significant effects in either cohort. The mediating role of age on the efficacy of (poly)phenols and exercise warrants further research.

Few studies assessed the combined effect of (poly)phenols and exercise-training in young athletes. Only one study recruited athletes (national level taekwondo athletes) (Gaamouri et al. 2019) and four studies recruited participants described as healthy or recreationally active $\left(\dot{V} \mathrm{O}_{2 \max / \text { peak }} \leq 50 \mathrm{ml} \cdot \mathrm{kg}^{-1} \cdot \mathrm{min}^{-1}\right)($ Ichinose et al. 2011; Schwarz et al. 2018; Thompson et al. 2018; Sadowska-Krępa et al. 2019). Sub-group analysis of these four studies (data not shown) revealed no effect of (poly)phenol supplementation on any of the outcomes they measured, suggesting training status may not influence the efficacy of (poly)phenols to mediate exercise training adaptations. However, more research is needed to confirm this given the small number of eligible studies. Changes in muscle strength were also only measured in untrained older adults, so the findings of the current study are unlikely to represent changes in younger adults, 
406

407

408

409

410

411

412

413

414

415

416

417

418

419

420

421

422

423

424

425

426

427

428

429

given strength adaptations are affected by training status and age (Lemmer et al. 2000; Ahtiainen et al. 2003).

This review had several limitations. Firstly, many of the included studies were hampered by low sample sizes. Only four studies performed a priori calculation to ensure sufficient statistical power (Giolo et al., 2018; Bagheri et al., 2019, 2020; Barbosa et al., 2019), such that many were probably not adequately powered to detect meaningful changes. Secondly, some studies were of poor quality, since they did not employ a double-blind design $(n=2)$ or include a placebo control group (e.g., exercise only) $(n=3)$. Thirdly, due to a lack of homogenous studies, it was not possible to conduct sub analysis to discern the influence of sex, and (poly)phenol dose and duration on the outcomes of the study. It should all be noted that most studies did not state when they provide supplements in relation to the exercise bouts (e.g., $1 \mathrm{~h}$ pre or post-exercise) and, thus, we could not assess whether supplement timing influenced the results. We suggest future studies report this information. Finally, as our analysis included only a few types of (poly)phenols, principally isoflavones and those from green tea, our findings are not representative of other (poly)phenols.

\section{Conclusion}

This review found no effect of (poly)phenols on exercise-induced changes in body fat, muscle strength and $\dot{V} \mathrm{O}_{2 \max }$. The small benefit of (poly)phenols for exercise capacity warrants further investigation since the observation is limited by the low number of studies. Overall, our findings suggest consuming (poly)phenol supplements alongside exercise training is unlikely to stimulate greater changes in performance or body composition, with the exception perhaps of isoflavones, which may enhance lean mass gains in post-menopausal females. These conclusions are limited by the small number of studies assessing the combined effects of exercise and (poly)phenol supplementation, irrespective of (poly)phenol type and dose. Future 
studies should employ rigorous study designs and ensure they are adequately powered to detect meaningful group effects. More in vivo research is needed on the combined and independent effects of other commonly consumed (poly)phenol supplements, such as curcumin, cocoa flavanols, and hydroxytyrosol, and the mediating role age and exercise type, to provide greater insight into the potential of (poly)phenol supplements to impact the adaptations to exercise training.

Financial Disclosure: None reported.

Funding/Support: No funding or support was received for this work.

\section{Figure legends}

Figure 1. Flow diagram of search strategy.

Figure 2. Risk of bias summary.

Figure 3. Forest plots for the effects of (poly)phenol supplementation on aerobic peak power output (A), exercise capacity (B), timed up and go test (C), upper-body strength (D), and lowerbody strength (E). Data are presented as random effect point estimates (SMD) with 95\% confidence intervals (CI) and the diamonds at the bottom of each forest plot corresponds to the overall effect estimate. Data are also presented as $\mathrm{MD} \pm 95 \% \mathrm{CI}(\mathrm{C})$.

Figure 4. Forest plots for the effects of (poly)phenol supplementation on adaptions to $\dot{V} \mathrm{O}_{2 \max }$ (A); sub-group analysis of supplement type on $\dot{V} \mathrm{O}_{2 \max },(\mathrm{B})$. Data are presented as random effect point estimates (SMD) with $95 \%$ confidence intervals (CI) and the diamonds at the bottom of each forest plot corresponds to the overall effect estimate.

Figure 5. Forest plots for the effects of (poly)phenol supplementation on changes in body fat (A); sub-group analysis of age on body fat, (B); sub-group analysis of supplement type on age (C). Data are presented as random effect point estimates (SMD) with 95\% confidence intervals 
453 (CI) and the diamonds at the bottom of each forest plot corresponds to the overall effect 454 estimate.

455 Figure 6. Forest plots for the effects of (poly)phenol supplementation on changes in lean mass

456 (A); sub-group analysis of supplement type on lean mass (B). Data are presented as random 457 effect point estimates (SMD) with 95\% confidence intervals (CI) and the diamonds at the 458 bottom of each forest plot corresponds to the overall effect estimate.

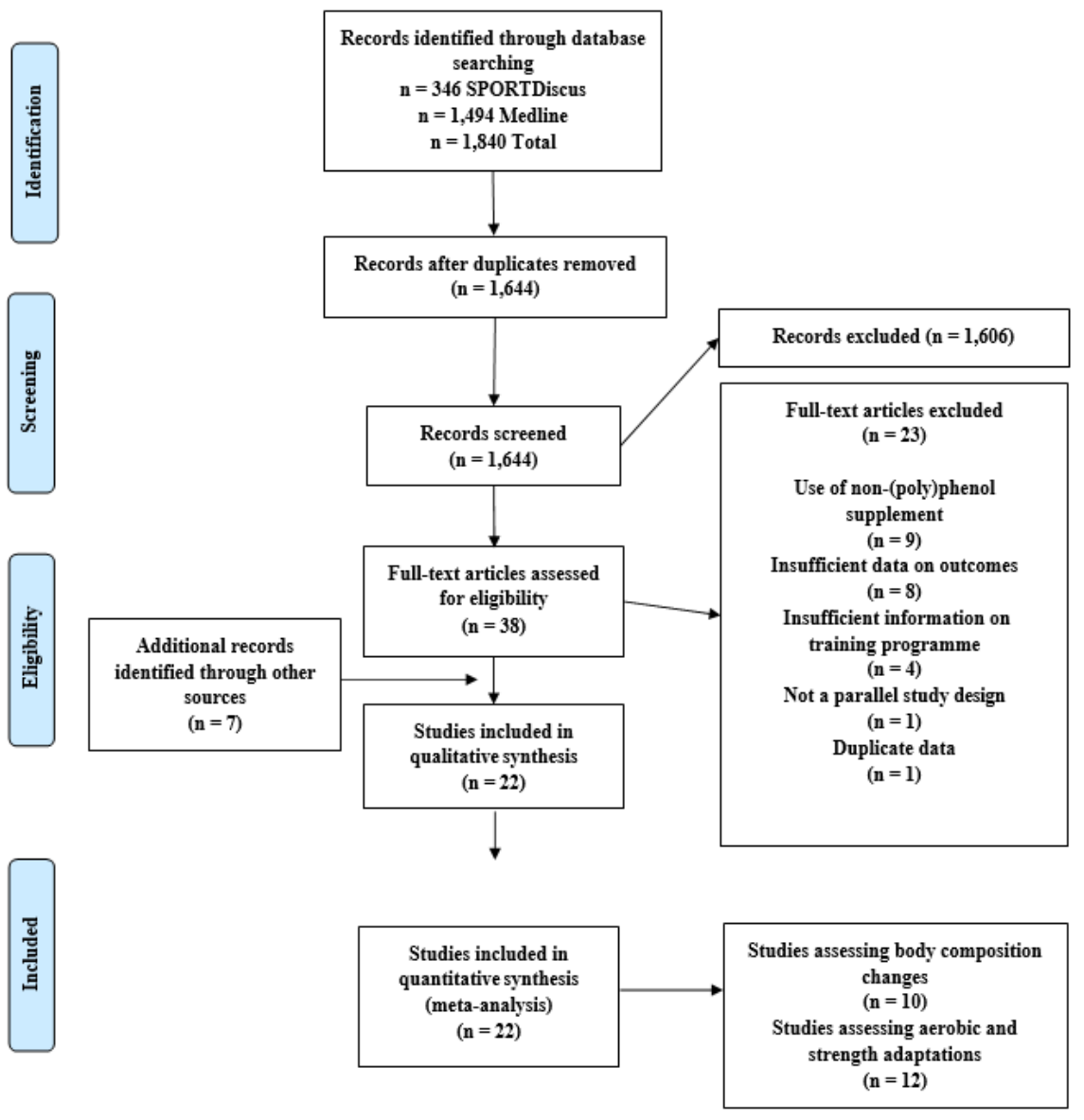


Random sequence generation (selection bias)

Allocation concealment (selection bias)

Blinding of participants and personnel (performance bias)

Blinding of outcome assessment (detection bias)

Incomplete outcome data (attrition bias)

Selective reporting (reporting bias)

Other bias
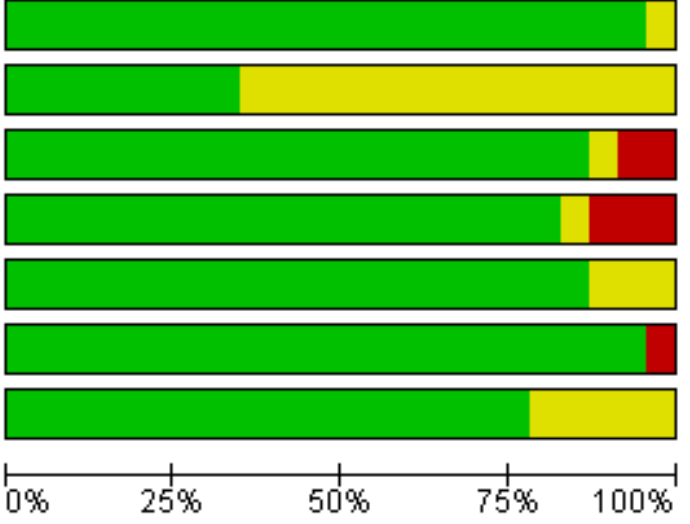

Low risk of bias

Unclear risk of bias

High risk of bias

461

462 
A

\begin{tabular}{|c|c|c|c|}
\hline Study or Subgroup & \multicolumn{2}{|r|}{ Std. Mean Difference } & $\begin{array}{l}\text { Std. Mean Difference } \\
\text { IV, Random, } 95 \% \mathrm{Cl}\end{array}$ \\
\hline Schwarz et al. (2018) & $34.4 \%$ & $-0.18[-1.08,0.72]$ & - ar \\
\hline Scribbans et al. (2014) & $29.2 \%$ & $0.06[-0.92,1.04]$ & \\
\hline Thompson et al. (2018) & $36.5 \%$ & $0.02[-0.85,0.90]$ & \\
\hline Total $(95 \% \mathrm{Cl})$ & $100.0 \%$ & $-0.04[-0.57,0.49]$ & \\
\hline $\begin{array}{l}\text { Heterogeneity: Tau } z=0 \text {. } \\
\text { Test for overall effect: } Z=\end{array}$ & $\begin{array}{l}\text { Chi }^{2}=0 \\
13(P=0\end{array}$ & $\mathrm{df}=2(\mathrm{P}=0.93) ; \mathrm{I}^{2}=0 \%$ & $\begin{array}{cccc}1 & 1 & 1 & 1 \\
-2 & -1 & 0 & 1 \\
\text { Favours control } & \text { Favours }\end{array}$ \\
\hline
\end{tabular}

B

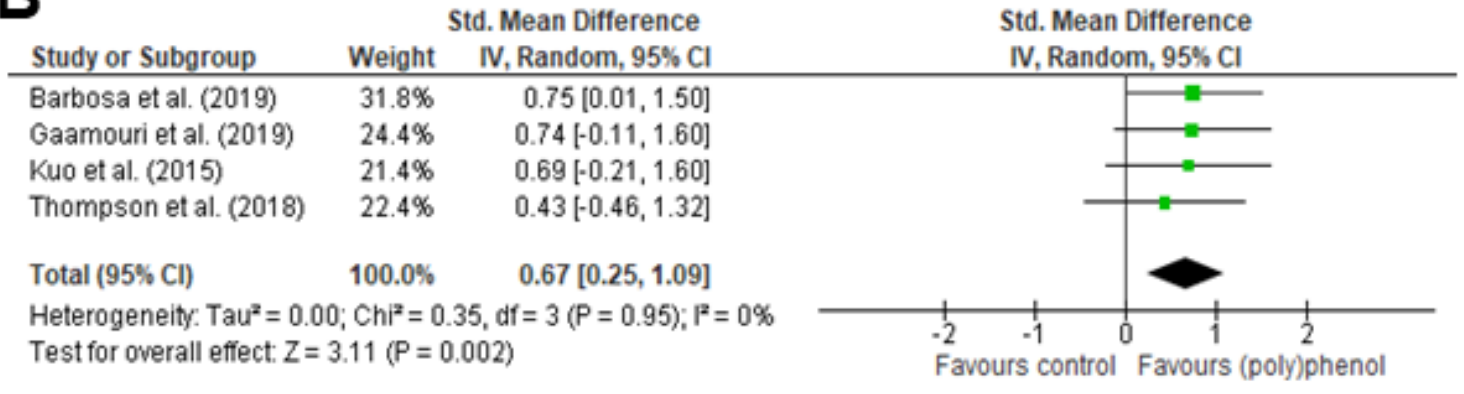

C

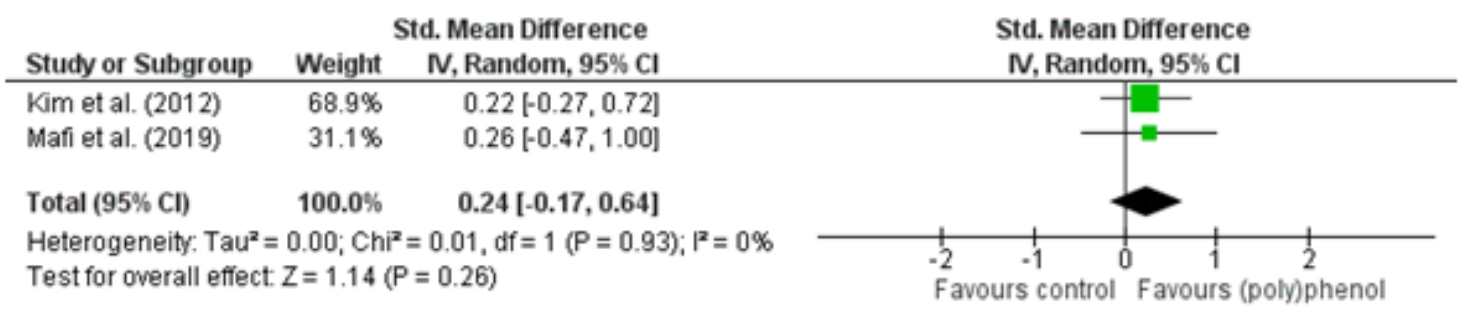

D

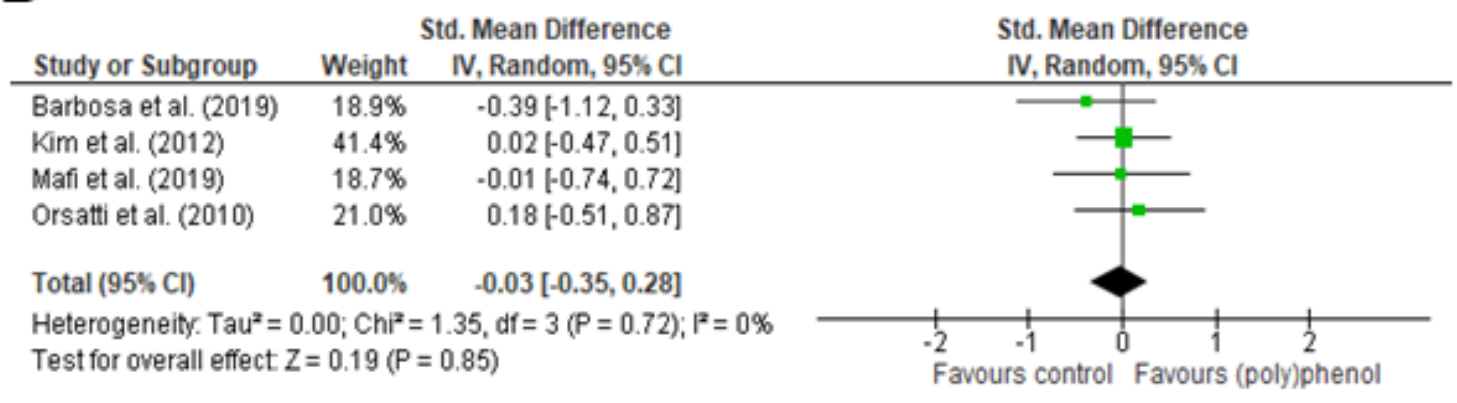

E

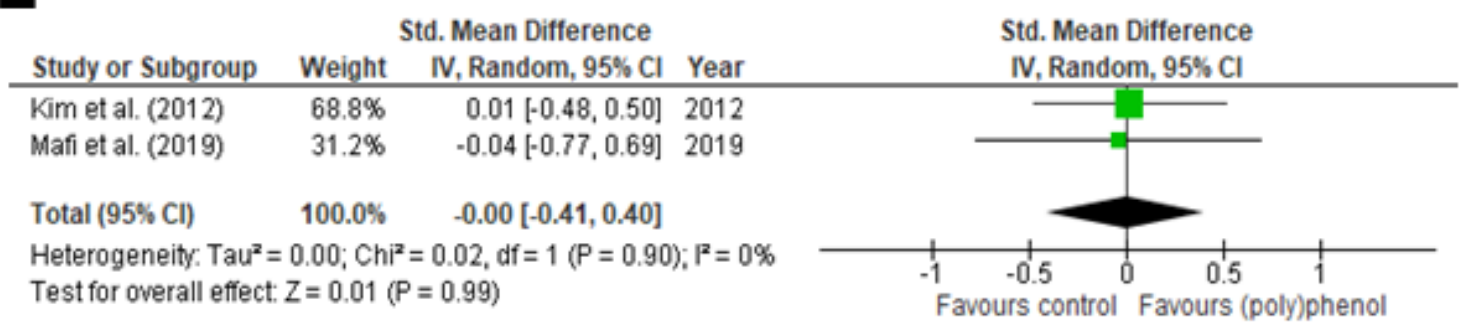




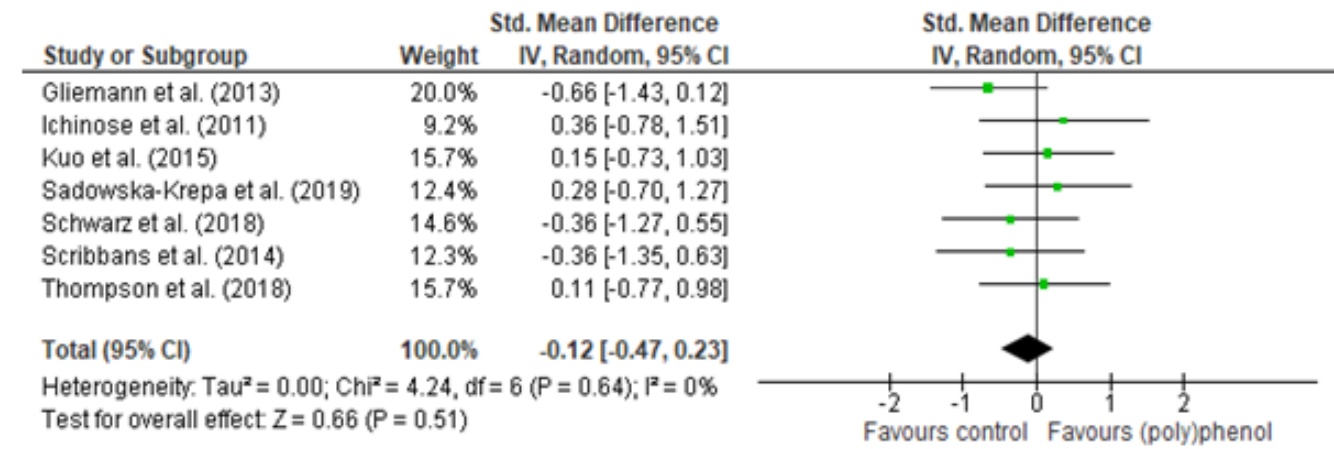

B

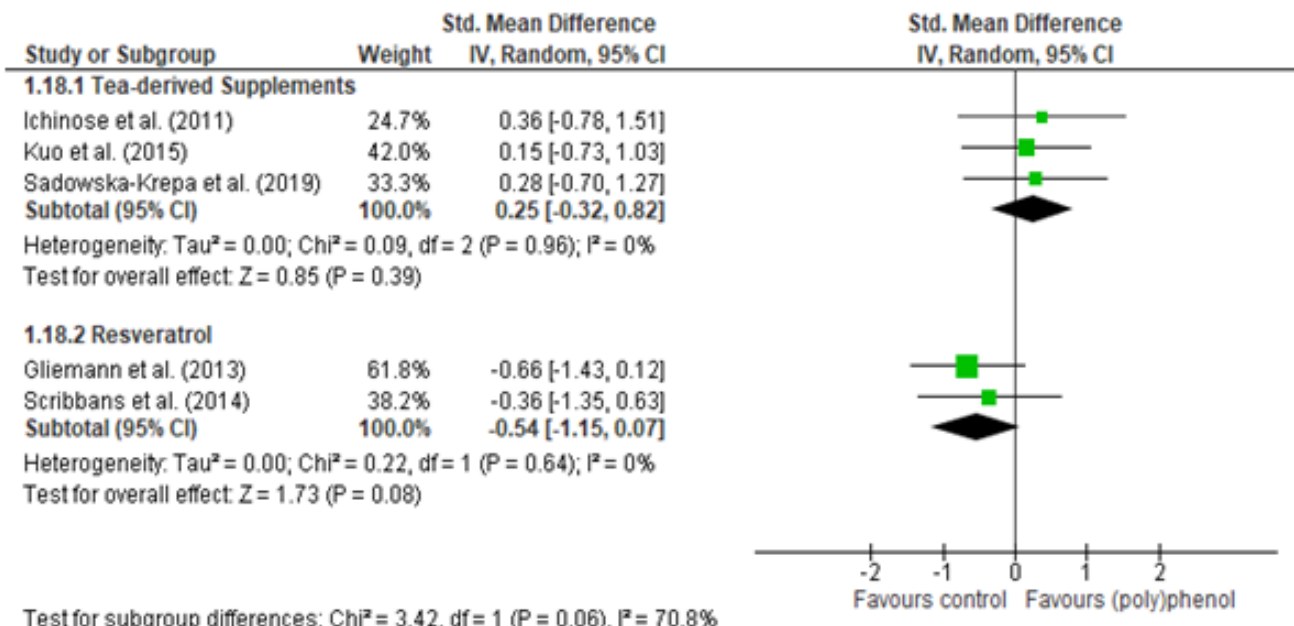


A

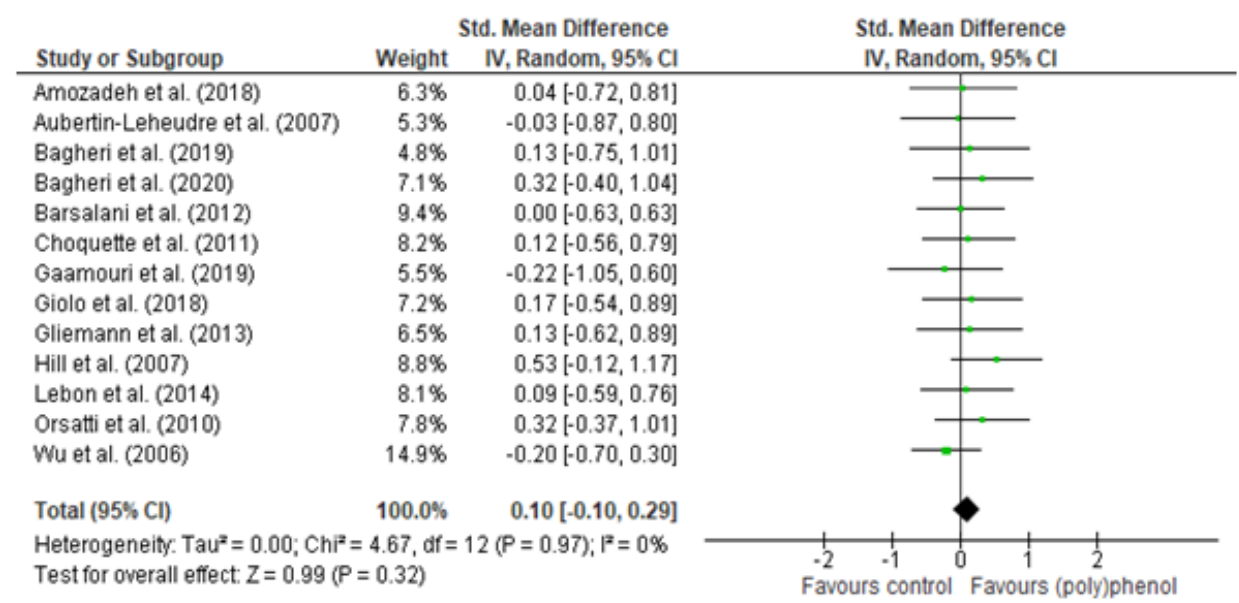

B

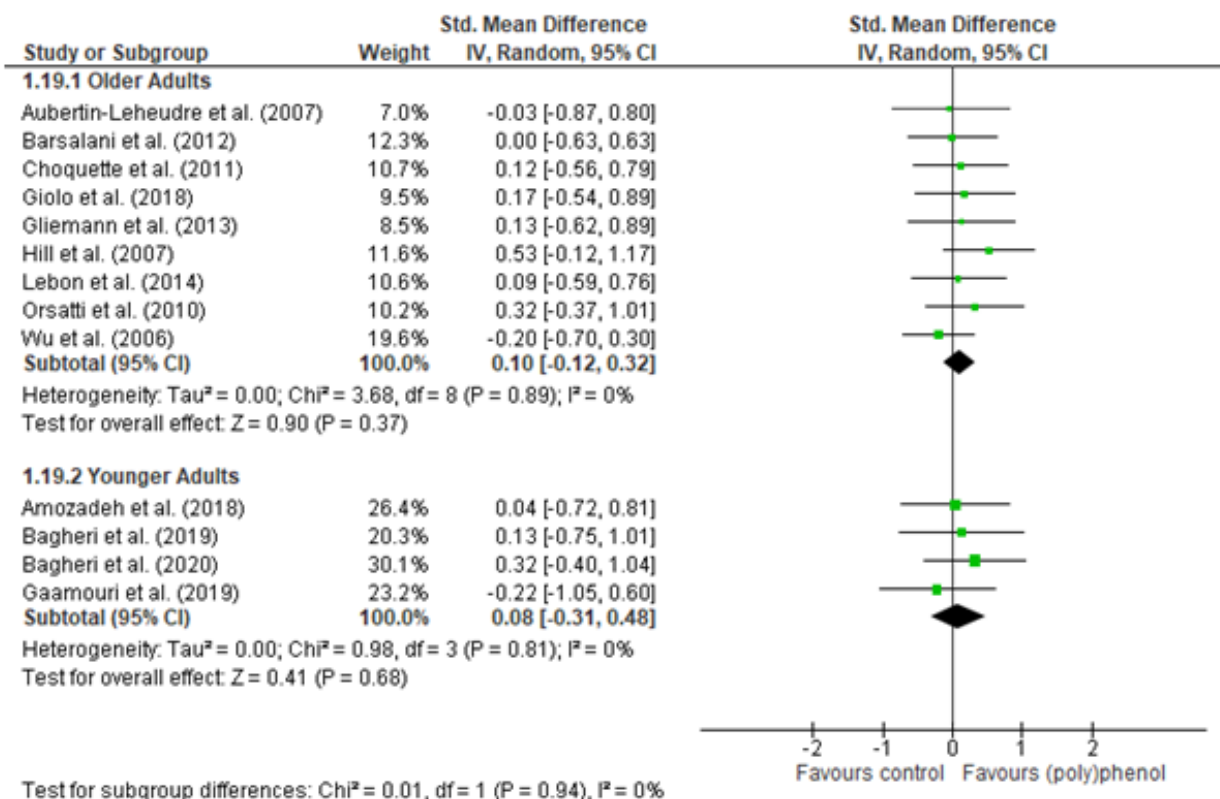

C

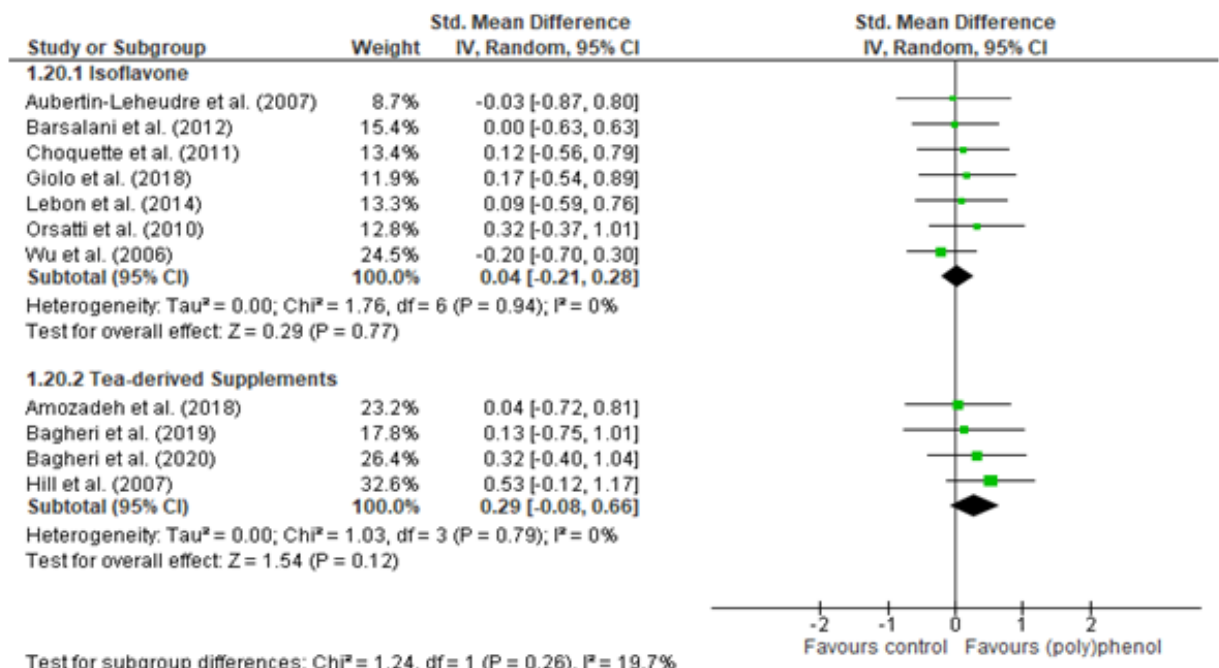


A

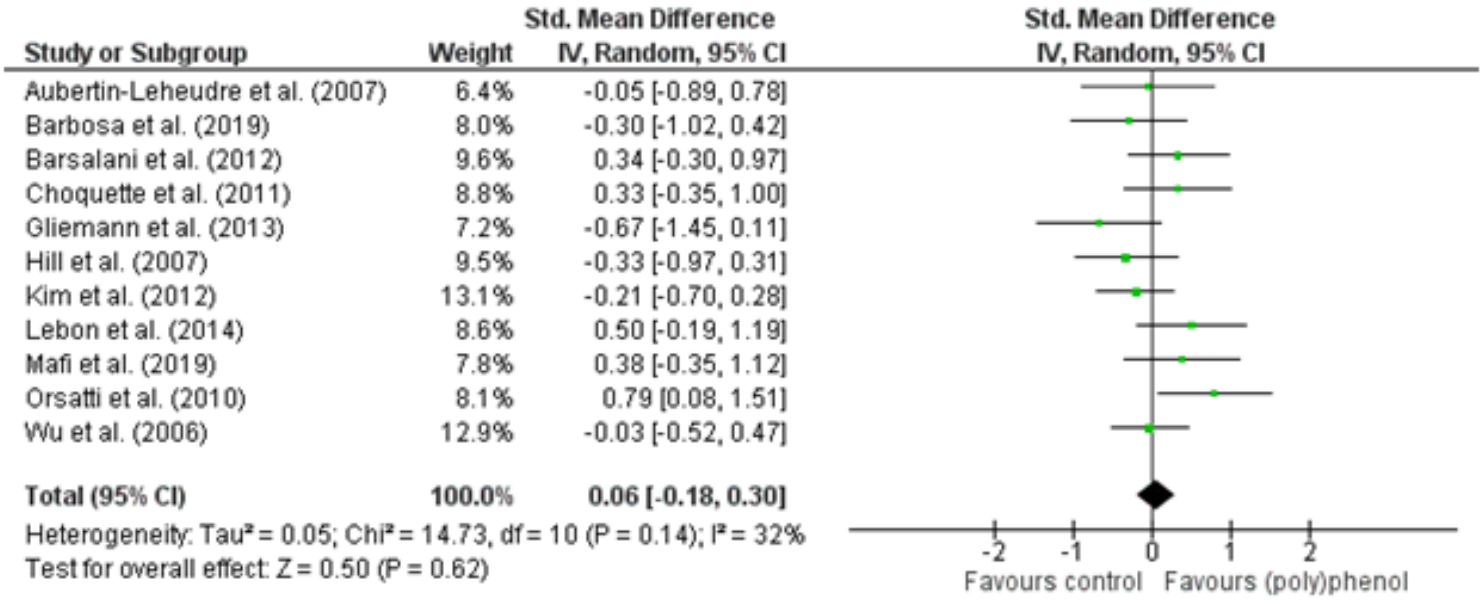

B

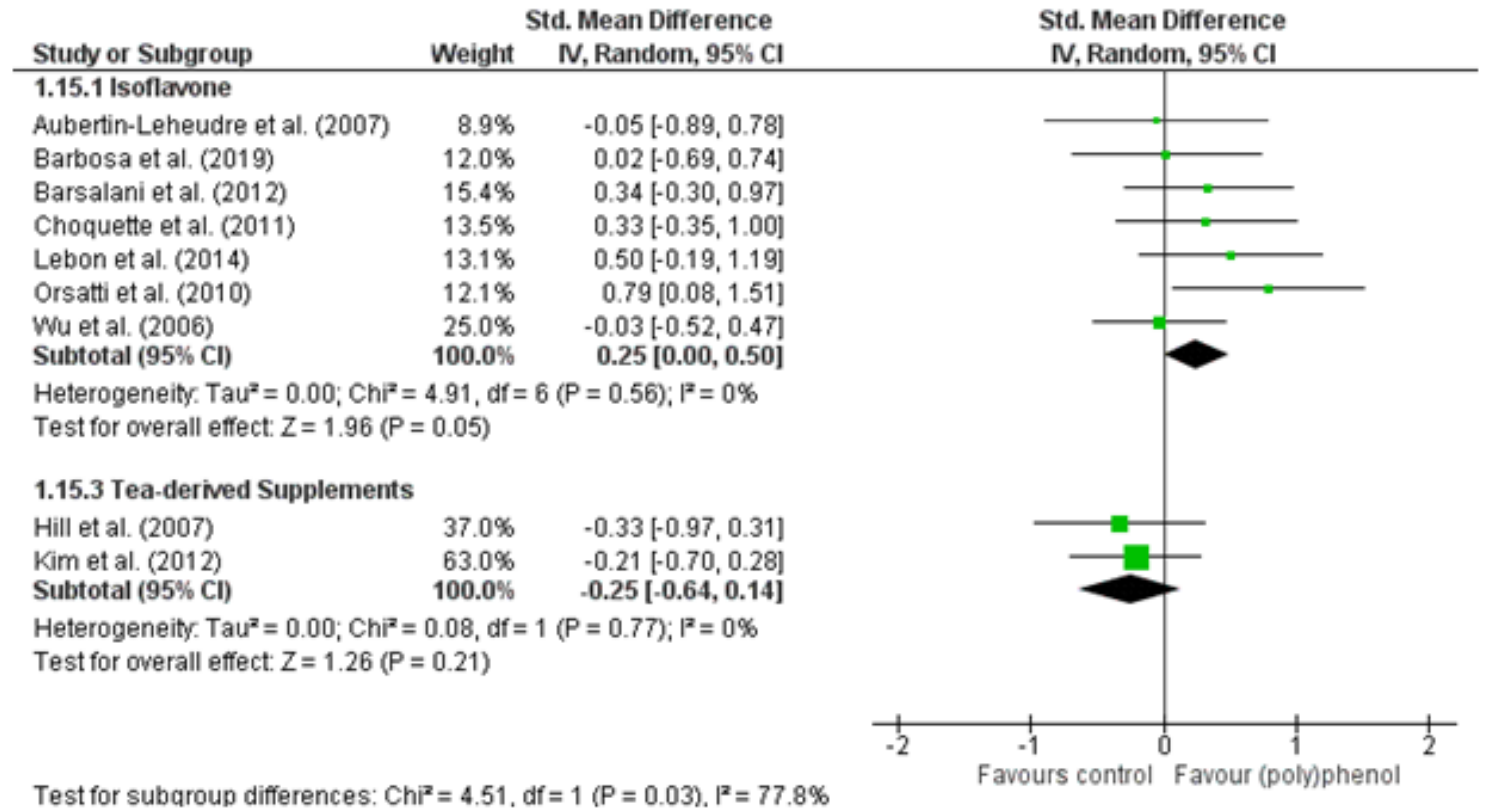


Table 1. A summary of the studies included in the systematic review and meta-analysis that measured effects of exercise training and (poly)phenol intake on body composition and performance.

\begin{tabular}{|c|c|c|c|c|c|c|c|c|}
\hline Study & Subjects & Age (years) & (Poly)phenol & Control & Exercise & Duration & Outcomes & Conclusion \\
\hline $\begin{array}{l}\text { Wu et al. } \\
(2006)\end{array}$ & $\begin{array}{l}\text { INT: } 31 \mathrm{~F} \\
\text { CON: } 31 \mathrm{~F} \\
\text { PMW }\end{array}$ & $\begin{array}{l}\text { INT: } 54 \pm 3 \\
\text { CON: } 53 \pm 3\end{array}$ & $\begin{array}{l}\text { ISO }(150 \\
\left.\text { mg•day }{ }^{-1}\right)\end{array}$ & Dextrin & $\begin{array}{l}\text { AT } 3 \times 1 \\
\text { h•week }\end{array}$ & 6 months & $\begin{array}{l}\text { FM (kg) } \\
\text { LBM (kg) }\end{array}$ & $\begin{array}{l}\text { ND for all } \\
\text { outcomes }\end{array}$ \\
\hline $\begin{array}{l}\text { Aubertin- } \\
\text { Leheudre et } \\
\text { al. (2007) }\end{array}$ & $\begin{array}{l}\text { INT: } 11 \mathrm{~F} \\
\text { CON: } 11 \mathrm{~F} \\
\text { OB/PMW }\end{array}$ & $\begin{array}{l}\text { INT: } 57 \pm 5 \\
\text { CON: } 58 \pm 5\end{array}$ & $\begin{array}{l}\text { ISO }(70 \\
\text { mg•day }\end{array}$ & $\begin{array}{l}\text { Placebo } \\
\text { (source } \\
\text { unclear) }\end{array}$ & $\begin{array}{l}\text { AT } 3 \times 1 \\
\text { h•week }\end{array}$ & 6 months $^{\text {a }}$ & $\begin{array}{l}\text { FM }(\mathrm{kg}) \\
\text { App FFM }(\mathrm{kg})\end{array}$ & $\begin{array}{l}\downarrow \text { FM with } \\
\text { INT } \\
\text { ND for FFM }\end{array}$ \\
\hline $\begin{array}{l}\text { Hill et al. } \\
(2007)\end{array}$ & $\begin{array}{l}\text { INT: } 19 \mathrm{~F} \\
\text { CON: } 19 \mathrm{~F} \\
\text { OB }\end{array}$ & $\begin{array}{l}\text { INT: } 45-70 \\
\text { CON: } 45-70\end{array}$ & $\begin{array}{l}\text { EGCG }(300 \\
\left.\text { mg•day }^{-1}\right)\end{array}$ & Lactose & $\begin{array}{l}\text { AT } 3 \times 45 \\
\text { min•week }\end{array}$ & 12 weeks & $\begin{array}{l}\mathrm{BF}(\Delta \mathrm{kg}) \\
\mathrm{LBM}(\Delta \mathrm{kg})\end{array}$ & $\begin{array}{l}\text { ND for all } \\
\text { outcomes }\end{array}$ \\
\hline $\begin{array}{l}\text { Orsatti et al. } \\
(2010)\end{array}$ & $\begin{array}{l}\text { INT: } 15 \mathrm{~F} \\
\text { CON: } 18 \mathrm{~F} \\
\text { OB/PMW }\end{array}$ & $\begin{array}{l}\text { INT: } 56 \pm 7 \\
\text { CON: } 57 \pm 9\end{array}$ & $\begin{array}{l}\text { ISO }(100 \\
\text { mg•day }\end{array}$ & Lactose & $\begin{array}{l}\text { RT } 2 \times \approx 1 \\
\text { h•week }{ }^{-1}\end{array}$ & 9 months & $\begin{array}{l}1 \mathrm{RM} \text { LE }(\% \\
\Delta) \\
\mathrm{MM}(\mathrm{kg}) \\
\mathrm{BF}(\%)\end{array}$ & $\begin{array}{l}\text { ND for all } \\
\text { outcomes }\end{array}$ \\
\hline $\begin{array}{l}\text { Barsalani et } \\
\text { al. (2012) }\end{array}$ & $\begin{array}{l}\text { INT: } 18 \mathrm{~F} \\
\text { CON: } 21 \mathrm{~F} \\
\text { OB/PMW }\end{array}$ & $\begin{array}{l}\text { INT: } 50-70 \\
\text { CON: } 50-70\end{array}$ & $\begin{array}{l}\text { ISO }(280 \\
\left.\text { mg•day }{ }^{-1}\right)\end{array}$ & Cellulose & $\begin{array}{l}\text { Mix } 3 \times \approx 1 \\
\text { h•week }^{-1} \text { b }\end{array}$ & 6 months & $\begin{array}{l}\text { FM }(\mathrm{kg}) \\
\text { LBM (kg) }\end{array}$ & $\begin{array}{l}\text { ND for all } \\
\text { outcomes }\end{array}$ \\
\hline $\begin{array}{l}\text { Gliemann et } \\
\text { al. }(2013)\end{array}$ & $\begin{array}{l}\text { INT: } 14 \mathrm{M} \\
\text { CON: } 13 \mathrm{M} \\
\text { H/NA }\end{array}$ & $\begin{array}{l}\text { INT: } 65 \pm 4 \\
\text { CON: } 65 \pm 4\end{array}$ & $\begin{array}{l}\operatorname{RSV}(250 \\
\left.\mathrm{mg} \bullet \text { day }^{-1}\right)\end{array}$ & $\begin{array}{l}\text { Placebo } \\
\text { (no } \\
\text { mention of } \\
\text { source) }\end{array}$ & $\begin{array}{l}\text { AT } 2 \times \approx 1 \\
\text { h॰week }{ }^{-1}+ \\
\text { CF } 1 \times \approx 1 \\
\text { h॰week }{ }^{-1}\end{array}$ & 8 weeks & $\begin{array}{l}\dot{V} \mathrm{O}_{2 \max } \\
\left(\mathrm{mL} \cdot \mathrm{min}^{-1} \bullet \mathrm{kg}^{-}\right. \\
\left.{ }^{1}\right) \\
\mathrm{BF}(\mathrm{kg}) \\
\mathrm{LBM}(\mathrm{kg})\end{array}$ & $\begin{array}{l}\downarrow \text { with INT for } \\
\dot{V} \mathrm{O}_{2 \max } \\
\text { ND for other } \\
\text { outcomes }\end{array}$ \\
\hline
\end{tabular}




\begin{tabular}{|c|c|c|c|c|c|c|c|c|}
\hline $\begin{array}{l}\text { Kim et al. } \\
\text { (2013) }\end{array}$ & $\begin{array}{l}\text { INT: } 32 \mathrm{~F} \\
\text { CON: } 32 \mathrm{~F} \\
\text { Sarcopenic }\end{array}$ & $\begin{array}{l}\text { INT: } 81 \pm 4 \\
\text { CON: } 80 \pm 4\end{array}$ & $\begin{array}{l}\mathrm{TC}(540 \\
\left.\mathrm{mg} \bullet \text { day }^{-1}\right)\end{array}$ & No placebo & $\begin{array}{l}\text { RT } 2 \times 1 \\
\text { h•week }\end{array}$ & 3 months & $\begin{array}{l}\text { TUG test } \\
\text { (min) } \\
\text { Grip strength } \\
(\mathrm{kg}) \\
\text { KE strength } \\
(\mathrm{Nm}) \\
\mathrm{MM}(\mathrm{kg})\end{array}$ & $\begin{array}{l}\text { ND for all } \\
\text { outcomes }\end{array}$ \\
\hline $\begin{array}{l}\text { Lebon et al. } \\
(2013)\end{array}$ & $\begin{array}{l}\text { INT: } 19 \mathrm{~F} \\
\text { CON: } 15 \mathrm{~F} \\
\text { OB/PMW }\end{array}$ & $\begin{array}{l}\text { INT: } 59 \pm 6 \\
\text { CON: } 60 \pm 3\end{array}$ & $\begin{array}{l}\text { ISO }(70 \\
\left.\text { mg•day }{ }^{-1}\right)\end{array}$ & Cellulose & $\begin{array}{l}\text { Mix } 3 \times 1 \\
\text { h•week } \text { - }^{-1} \text { b }\end{array}$ & 6 months & $\begin{array}{l}\text { FM }(\mathrm{kg}) \\
\text { MMI }\left(\mathrm{kg} \cdot \mathrm{m}^{-2}\right)\end{array}$ & $\begin{array}{l}\downarrow \text { FM with } \\
\text { INT } \\
\text { ND for MMI }\end{array}$ \\
\hline $\begin{array}{l}\text { Giolo et al. } \\
(2018)\end{array}$ & $\begin{array}{l}\text { INT: } 17 \mathrm{~F} \\
\text { CON: } 15 \mathrm{~F} \\
\text { PMW }\end{array}$ & $\begin{array}{l}\text { INT: } 56 \pm 22 \\
\text { CON: } 53 \pm 19\end{array}$ & $\begin{array}{l}\text { ISO }(100 \\
\left.\text { mg•day }{ }^{-1}\right)\end{array}$ & $\begin{array}{l}\text { Corn } \\
\text { starch }\end{array}$ & $\begin{array}{l}\text { Mix } 3 \times \approx 1 \\
\text { h•week }\end{array}$ & 10 weeks & FM (kg) & ND \\
\hline $\begin{array}{l}\text { Amozadeh et } \\
\text { al. (2018) }\end{array}$ & $\begin{array}{l}\text { INT: } 13 \mathrm{~F} \\
\text { CON: } 13 \mathrm{~F} \\
\text { OB }\end{array}$ & $\begin{array}{l}\text { INT: } 28 \pm 7 \\
\text { CON: } 27 \pm 7\end{array}$ & $\begin{array}{l}\text { GT }\left(99 \mathrm{mg} \bullet \text { day }^{-}\right. \\
\left.{ }^{1}\right)\end{array}$ & No placebo & $\begin{array}{l}\text { AT } 3 \times 80-90 \\
\text { min•week }{ }^{-1}\end{array}$ & 8 weeks & $\mathrm{BF}(\%)$ & ND \\
\hline $\begin{array}{l}\text { Barbosa et al. } \\
\text { (2019) }\end{array}$ & $\begin{array}{l}\text { INT: } 16 \mathrm{~F} \\
\text { CON: } 14 \mathrm{~F} \\
\text { PMW }\end{array}$ & $\begin{array}{l}\text { INT: } 56 \pm 6 \\
\text { CON: } 53 \pm 4\end{array}$ & $\begin{array}{l}\text { ISO }(100 \\
\left.\text { mg•day }{ }^{-1}\right)\end{array}$ & $\begin{array}{l}\text { Corn } \\
\text { starch }\end{array}$ & $\begin{array}{l}\text { Mix } 3 \times \approx 1 \\
\text { h•week }\end{array}$ & 5 weeks & $\begin{array}{l}\text { LBM (\%) } \\
\text { 1RM LP (kg) } \\
\text { 6MWT (min) }\end{array}$ & $\begin{array}{l}\text { ND for all } \\
\text { outcomes }\end{array}$ \\
\hline $\begin{array}{l}\text { Bagheri et al. } \\
\text { (2019) }\end{array}$ & $\begin{array}{l}\text { INT: } 10 \mathrm{~F} \\
\text { CON: } 10 \mathrm{~F} \\
\text { OB }\end{array}$ & $\begin{array}{l}\text { INT: } 38 \pm 2 \\
\text { CON: } 40 \pm 4\end{array}$ & $\begin{array}{l}\text { GTE }(500 \\
\left.\text { mg•day }{ }^{-1}\right)\end{array}$ & $\begin{array}{l}\text { Chickpea } \\
\text { flour }\end{array}$ & $\begin{array}{l}\text { AT } 3 \times 1 \\
\text { h•week }\end{array}$ & 8 weeks & BF (\%) & $\downarrow$ with INT \\
\hline $\begin{array}{l}\text { Gaamouri et } \\
\text { al. }(2019)\end{array}$ & $\begin{array}{l}\text { INT: } 5 \text { F } 6 \text { M } \\
\text { CON: } 6 \text { F } 6 \\
\text { M }\end{array}$ & $\begin{array}{l}\text { INT: } 22 \pm 1 \\
\text { CON: } 22 \pm 1\end{array}$ & $\begin{array}{l}\text { Carob extract } \\
\left(208 \mathrm{mg} \cdot \mathrm{day}^{-1}\right)\end{array}$ & $\begin{array}{l}\text { Taste- } \\
\text { matched } \\
\text { placebo } \\
\text { drink }\end{array}$ & $\begin{array}{l}\text { TWD } 4 \times 45- \\
60 \text { min } \text { week }^{-1}\end{array}$ & 6 weeks & $\begin{array}{l}\text { Yo-Yo IR1 } \\
\text { (m) } \\
\text { BF (\%) }\end{array}$ & $\begin{array}{l}\uparrow \text { with INT for } \\
\text { Yo-Yo IR1 } \\
\text { ND for BF }\end{array}$ \\
\hline $\begin{array}{l}\text { Mafi et al. } \\
\text { (2019) }\end{array}$ & $\begin{array}{l}\text { INT: } 15 \mathrm{M} \\
\text { CON: } 14 \mathrm{M} \\
\text { Sarcopenic }\end{array}$ & $\begin{array}{l}\text { INT: } 69 \pm 3 \\
\text { CON: } 69 \pm 2\end{array}$ & $\begin{array}{l}\text { EPI }\left(1 \mathrm{mg} \cdot \mathrm{kg}^{-}\right. \\
\left.{ }^{1} \text { day }^{-1}\right)\end{array}$ & No placebo & $\begin{array}{l}\text { RT } 3 \times 1 \\
\text { h•week }\end{array}$ & 8 weeks & $\begin{array}{l}1 \mathrm{RM} \text { LP } \\
(\mathrm{kg} \Delta) \\
1 \mathrm{RM} \mathrm{CP} \\
(\operatorname{kg} \Delta) \\
\mathrm{TUG}(\sec \Delta)\end{array}$ & $\begin{array}{l}\downarrow \text { with INT for } \\
\text { 1RM strength } \\
\text { ND for TUG } \\
\text { and AppMMI }\end{array}$ \\
\hline
\end{tabular}




\begin{tabular}{|c|c|c|c|c|c|c|c|c|}
\hline & & & & & & & $\begin{array}{l}\text { AppMMI } \\
\left(\mathrm{kg} \cdot \mathrm{m}^{2} \Delta\right)\end{array}$ & \\
\hline $\begin{array}{l}\text { Bagheri et al. } \\
(2020)\end{array}$ & $\begin{array}{l}\text { INT: } 15 \mathrm{M} \\
\text { CON: } 15 \mathrm{M} \\
\text { OB }\end{array}$ & $\begin{array}{l}\text { INT: } 45 \pm 3 \\
\text { CON: } 44 \pm 3\end{array}$ & $\begin{array}{l}\text { GTE }(500 \\
\left.\text { mg・day }{ }^{-1}\right)\end{array}$ & $\begin{array}{l}\text { Chickpea } \\
\text { flour }\end{array}$ & $\begin{array}{l}\text { AT } 3 \times 1 \\
\text { h•week }\end{array}$ & 8 weeks & $\mathrm{BF}(\%)$ & $\downarrow$ with INT \\
\hline
\end{tabular}

INT, intervention; CON, control; F, females; M, males; PMW, postmenopausal; OB, obese; H, healthy;; NA, non-active ISO, isoflavone; mg, milligram; AT, aerobic training; RT, resistance training; h, hour; FM, fat mass; LBM, lean body mass; ND, no difference; App, appendicular; FFM, fat free mass; EGCG, epigallocatechin gallate; EPI, epicatechin; GTE, green tea extract; min, minute; 1 RM, 1 repetition maximum; BF, body fat; $\Delta$, delta change from baseline; $\approx$, approximately; Mix, combination of resistance training and aerobic training; MMI, muscle mass index; $\downarrow$, lower; $\mathrm{m}^{2}$, meters squared; GT, green tea; \%, percentage; RSV, resveratrol; $\dot{V} \mathrm{O}_{2 \max }$, maximal aerobic capacity; $\Delta$, delta change from baseline; KE, knee extension; TWD, taekwondo; 6MWT, 6 minute walk test; CP, chest press; LP, leg press; TUG, timed up and go; Nm, torque; Yo-Yo IR1, Yo-Yo intermittent recovery test; $\mathrm{m}$, meter; $\mathrm{m}^{2}$, meters squared. Data presented as mean \pm SD. ${ }^{a}$ supplementation began 6 months prior to the exercise intervention; ${ }^{b}$ time distributed evenly between RT and AT per day.

Table 2. A summary of the studies included in the systematic review and meta-analysis that measured performance and strength adaptations to exercise training and (poly)phenol intake.

\begin{tabular}{|c|c|c|c|c|c|c|c|c|}
\hline Study & Subjects & Age (years) & (Poly)phenol & Control & Exercise & Duration & Outcomes & Conclusion \\
\hline $\begin{array}{l}\text { Ichinose et } \\
\text { al. (2011) }\end{array}$ & $\begin{array}{l}\text { INT: } 6 \mathrm{M} \\
\text { CON: } 6 \mathrm{M} \\
\text { H/RA }\end{array}$ & $\begin{array}{l}\text { INT: } 23 \pm 5 \\
\text { CON: } 23 \pm 5\end{array}$ & $\begin{array}{l}\text { GTE }(573 \\
\left.\text { mg・day }{ }^{-1}\right)\end{array}$ & $\begin{array}{l}\text { Taste- } \\
\text { matched } \\
\text { placebo } \\
\text { drink }\end{array}$ & $\begin{array}{l}\text { AT } 3 \times 1 \\
\text { h•week }{ }^{-1}\end{array}$ & 10 weeks & $\begin{array}{l}\dot{\dot{V}} \mathrm{O}_{2 \text { peak }}\left(\mathrm{L} \cdot \mathrm{min}^{-}\right. \\
\left.{ }^{-}\right)\end{array}$ & ND \\
\hline $\begin{array}{l}\text { Scribbans et } \\
\text { al. (2014) }\end{array}$ & $\begin{array}{l}\text { INT: } 8 \mathrm{M} \\
\text { CON: } 8 \mathrm{M} \\
\text { H/NA }\end{array}$ & $\begin{array}{l}\text { INT: } 21 \pm 3 \\
\text { CON: } 22 \pm 3\end{array}$ & $\begin{array}{l}\operatorname{RSV}(150 \\
\left.\mathrm{mg} \cdot \text { day }^{-1}\right)\end{array}$ & Cellulose & $\begin{array}{l}\text { SIT } 3 \times 5 \\
\min \bullet \text { week }^{-1}\end{array}$ & 28 days & $\begin{array}{l}\dot{V} \mathrm{O}_{2 \text { peak }} \\
\left(\mathrm{mL} \cdot \mathrm{min}^{-1} \cdot \mathrm{kg}^{-1}\right) \\
\text { PPO }(\mathrm{W})\end{array}$ & $\begin{array}{l}\downarrow \text { with INT } \\
\text { in all } \\
\text { outcomes }\end{array}$ \\
\hline $\begin{array}{l}\text { Kuo et al. } \\
(2015)\end{array}$ & $\begin{array}{l}\text { INT: } 10 \mathrm{M} \\
\text { CON: } 10 \mathrm{M} \\
\text { H/NA }\end{array}$ & $\begin{array}{l}\text { INT: } 21 \pm 3 \\
\text { CON: } 20 \pm 3\end{array}$ & $\begin{array}{l}\text { GTE }(207 \\
\left.\text { mg・day }{ }^{-1}\right)\end{array}$ & Starch & $\begin{array}{l}\text { AT } 3 \times 20 \\
\text { min } \bullet \text { week }^{-1}\end{array}$ & 4 weeks & $\begin{array}{l}\dot{V} \mathrm{O}_{2 \max } \\
\left(\mathrm{mL} \cdot \mathrm{min}^{-1} \cdot \mathrm{kg}^{-1}\right) \\
\text { TTE }(\mathrm{sec})\end{array}$ & $\begin{array}{l}\text { ND for all } \\
\text { outcomes }\end{array}$ \\
\hline
\end{tabular}




\begin{tabular}{|c|c|c|c|c|c|c|c|c|}
\hline $\begin{array}{l}\text { Schwarz et } \\
\text { al. (2018) }\end{array}$ & $\begin{array}{l}\text { INT: } 10 F+M \\
\text { CON: } 9 F+M \\
\text { H/RA }\end{array}$ & $\begin{array}{l}\text { INT: } 21 \pm 2 \\
\text { CON: } 21 \pm 2\end{array}$ & $\begin{array}{l}\text { EPI }(200 \\
\left.\text { mg•day }^{-1}\right)\end{array}$ & Cellulose & $\begin{array}{l}\text { AT } 4 \times 40-60 \\
{\text { min } • w_{e e k}}^{-1}\end{array}$ & 4 weeks & $\begin{array}{l}\dot{V} \mathrm{O}_{2 \max } \\
\left(\mathrm{mL} \cdot \mathrm{min}^{-1} \cdot \mathrm{kg}^{-1}\right) \\
\text { PPO (W) }\end{array}$ & $\begin{array}{l}\downarrow \dot{V} \mathrm{O}_{2 \max } \\
\text { with INT } \\
\text { ND in PPO }\end{array}$ \\
\hline $\begin{array}{l}\text { Thompson } \\
\text { et al. (2018) }\end{array}$ & $\begin{array}{l}\text { INT: } 4 \text { F } 6 \text { M } \\
\text { CON: } 4 \text { F } 6 \mathrm{M} \\
\text { H/RA }\end{array}$ & $\begin{array}{l}\text { INT: } 25 \pm 7 \\
\text { CON: } 25 \pm 3\end{array}$ & $\begin{array}{l}\text { BRJ }(6.4 \\
\left.\text { mmol•day }{ }^{-1}\right)\end{array}$ & $\mathrm{KNO}_{3}$ & $\begin{array}{l}\text { SIT } 4 \times \approx 2-5 \\
\text { min•week }{ }^{-1}\end{array}$ & 28 days & $\begin{array}{l}\dot{V} \mathrm{O}_{2 \text { peak }}\left({\mathrm{L} \cdot \mathrm{min}^{-}}^{-}\right. \\
\left.{ }^{1}\right) \\
\mathrm{TTE}(\mathrm{sec}) \\
\mathrm{PPO}(\mathrm{W})\end{array}$ & $\begin{array}{l}\uparrow \text { with INT } \\
\text { for } \dot{V} \mathrm{O}_{2 \text { peak }} \\
\text { and TTE } \\
\text { ND for } \\
\text { PPO }\end{array}$ \\
\hline $\begin{array}{l}\text { Sawdoska- } \\
\text { krępa et al. } \\
\text { (2019) }\end{array}$ & $\begin{array}{l}\text { INT: } 8 \mathrm{M} \\
\text { CON: } 8 \mathrm{M} \\
\text { H/RA }\end{array}$ & $\begin{array}{l}\text { INT: } 23 \pm 2 \\
\text { CON: } 22 \pm 1\end{array}$ & $\begin{array}{l}\text { GTE }(490 \\
\left.\text { mg•day }{ }^{-1}\right)\end{array}$ & Cellulose & $\begin{array}{l}\text { CF } 5 \times \approx 1 \\
\text { h॰week }\end{array}$ & 6 weeks & $\begin{array}{l}\dot{V} \mathrm{O}_{2 \text { peak }} \\
\left(\mathrm{mL} \cdot \mathrm{min}^{-1} \cdot \mathrm{kg}^{-1}\right)\end{array}$ & ND \\
\hline
\end{tabular}

INT, intervention; CON, control; F, female; M, male; H, healthy; RA, recreationally active; NA, non-active; g, grams; ISO, isoflavone; mg, milligram; h, hour; ND, no difference; GTE, green tea extract; $\mathrm{AT}$, aerobic training; $\dot{V} \mathrm{O}_{2 \text { peak }}$, peak oxygen consumption; min, minute; RSV, resveratrol; $\mathrm{CF}$, CrossFit; $\approx$, approximately; $\dot{V} \mathrm{O}_{2 \max }$, maximal oxygen consumption; $\mathrm{mL}$, millilitre; LBM, lean body mass; $\downarrow$, lower; SIT, sprint interval training; PPO, peak power output; W, watts; TTE, time to exhaustion; sec, seconds; EPI, epicatechin; BRJ, beetroot juice; L, litre; mmol, millimole; $\mathrm{KNO}_{3}$, potassium nitrate; $\uparrow$, higher; Data presented as mean $\pm \mathrm{SD}$. 


\section{Reference list}

Ahtiainen, Juha P., Arto Pakarinen, Markku Alen, William J. Kraemer, and Keijo Häkkinen. 2003. "Muscle Hypertrophy, Hormonal Adaptations and Strength Development during Strength Training in Strength-Trained and Untrained Men.” European Journal of Applied Physiology. https://doi.org/10.1007/s00421-003-0833-3.

Amozadeh, Hajar, Ramin Shabani, and Marzieh Nazari. 2018. "The Effect of Aerobic Training and Green Tea Supplementation on Cardio Metabolic Risk Factors in Overweight and Obese Females: A Randomized Trial.” International Journal of Endocrinology and Metabolism. https://doi.org/10.5812/ijem.60738.

Arts, Ilja C.W., and Peter C.H. Hollman. 2005. "Polyphenols and Disease Risk in Epidemiologic Studies.” The American Journal of Clinical Nutrition. https://doi.org/10.1093/ajen/81.1.317s.

Aubertin-Leheudre, Mylène, Christine Lord, Abdelouahed Khalil, and Isabelle J Dionne. 2007. "Effect of 6 Months of Exercise and Isoflavone Supplementation on Clinical Cardiovascular Risk Factors in Obese Postmenopausal Women: A Randomized, DoubleBlind Study." Menopause (New York, N.Y.) 14 (4): 624-29. http://search.ebscohost.com/login.aspx?direct=true $\& d b=$ cmedm\&AN=17290158\&site= ehost-live.

Bagheri, Reza, Amir Rashidlamir, Damoon Ashtary-Larky, Alexei Wong, Brandon Grubbs, Mohamad S Motevalli, Julien S Baker, Ismail Laher, and Hassane Zouhal. 2020. "Effects of Green Tea Extract Supplementation and Endurance Training on Irisin, proInflammatory Cytokines, and Adiponectin Concentrations in Overweight Middle-Aged Men.” European Journal of Applied Physiology 120 (4): 915-23.

http://search.ebscohost.com/login.aspx?direct=true\&db=s3h\&AN=142554197\&site=eho st-live.

Barbosa, Cinthia D, Juliene G Costa, Jéssica S Giolo, Luana T Rossato, Paula C Nahas, Igor M Mariano, Jaqueline P Batista, Guilherme M Puga, and Erick P de Oliveira. 2019. "Isoflavone Supplementation plus Combined Aerobic and Resistance Exercise Do Not Change Phase Angle Values in Postmenopausal Women: A Randomized PlaceboControlled Clinical Trial.” Experimental Gerontology 117 (March): 31-37. https://doi.org/10.1016/j.exger.2018.08.007. 
Barsalani, R, E Riesco, J-M Lavoie, and I J Dionne. 2013. "Effect of Exercise Training and Isoflavones on Hepatic Steatosis in Overweight Postmenopausal Women." Climacteric : The Journal of the International Menopause Society 16 (1): 88-95. https://doi.org/10.3109/13697137.2012.662251.

Bidonde, Julia, Angela J. Busch, Ina van der Spuy, Susan Tupper, Soo Y. Kim, and Catherine Boden. 2017. "Whole Body Vibration Exercise Training for Fibromyalgia." Cochrane Database of Systematic Reviews. https://doi.org/10.1002/14651858.CD011755.pub2.

Borges, Nattai, Peter Reaburn, Matthew Driller, and Christos Argus. 2016. "Age-Related Changes in Performance and Recovery Kinetics in Masters Athletes: A Narrative Review." Journal of Aging and Physical Activity. https://doi.org/10.1123/japa.20150021.

Bowtell, Joanna, and Vincent Kelly. 2019. "Fruit-Derived Polyphenol Supplementation for Athlete Recovery and Performance." Sports Medicine. https://doi.org/10.1007/s40279018-0998-x.

Bravo, Laura. 2009. "Polyphenols: Chemistry, Dietary Sources, Metabolism, and Nutritional Significance." Nutrition Reviews. https://doi.org/10.1111/j.1753-4887.1998.tb01670.x.

Bruns, Danielle R., Sarah E. Ehrlicher, Shadi Khademi, Laurie M. Biela, Frederick F. Peelor, Benjamin F. Miller, and Karyn L. Hamilton. 2018. "Differential Effects of Vitamin C or Protandim on Skeletal Muscle Adaptation to Exercise." Journal of Applied Physiology (Bethesda, Md. : 1985). https://doi.org/10.1152/japplphysiol.00277.2018.

Choquette, Stéphane, Éléonor Riesco, Éric Cormier, Tommy Dion, Mylène AubertinLeheudre, and Isabelle J Dionne. 2011. "Effects of Soya Isoflavones and Exercise on Body Composition and Clinical Risk Factors of Cardiovascular Diseases in Overweight Postmenopausal Women: A 6-Month Double-Blind Controlled Trial.” The British Journal of Nutrition 105 (8): 1199-1209. https://doi.org/10.1017/S0007114510004897.

Christensen, Lars Porskjær, and Kathrine Bisgaard Christensen. 2013. "The Role of Direct and Indirect Polyphenolic Antioxidants in Protection Against Oxidative Stress." In Polyphenols in Human Health and Disease. https://doi.org/10.1016/B978-0-12-3984562.00023-2.

Clifford, Tom. 2019. "Nutritional and Pharmacological Interventions to Expedite Recovery 
Following Muscle-Damaging Exercise in Older Adults: A Narrative Review of the Literature." Journal of Aging and Physical Activity. https://doi.org/10.1123/japa.20180351.

Close, Graeme L., Tony Ashton, Tim Cable, Dominic Doran, Chris Holloway, Frank McArdle, and Don P. M. MacLaren. 2006. "Ascorbic Acid Supplementation Does Not Attenuate Post-Exercise Muscle Soreness Following Muscle-Damaging Exercise but May Delay the Recovery Process." British Journal of Nutrition. https://doi.org/10.1079/bjn20061732.

Costa, Juliene G, Jéssica S Giolo, Igor M Mariano, Jaqueline P Batista, Ana Luiza A Ribeiro, Tállita Cristina F Souza, Erick P de Oliveira, Ana Paula M Resende, and Guilherme M Puga. 2017. "Combined Exercise Training Reduces Climacteric Symptoms without the Additive Effects of Isoflavone Supplementation: A Clinical, Controlled, Randomised, Double-Blind Study." Nutrition and Health 23 (4): 271-79. https://doi.org/10.1177/0260106017727359.

Crozier, Alan, Takao Yokota, Indu B. Jaganath, Serena Marks, Michael Saltmarsh, and Michael N. Clifford. 2007. "Secondary Metabolites in Fruits, Vegetables, Beverages and Other Plant-Based Dietary Components.” In Plant Secondary Metabolites: Occurrence, Structure and Role in the Human Diet. https://doi.org/10.1002/9780470988558.ch7.

Cuadrado, Antonio, Gina Manda, Ahmed Hassan, Maria Jose Alcaraz, Coral Barbas, Andreas Daiber, Pietro Ghezzi, et al. 2018. “Transcription Factor NRF2 as a Therapeutic Target for Chronic Diseases: A Systems Medicine Approach." Pharmacological Reviews 70 (2): 348-83. https://doi.org/https://dx.doi.org/10.1124/pr.117.014753.

Davis, J. Mark, E. Angela Murphy, Martin D. Carmichael, and Ben Davis. 2009a. "Quercetin Increases Brain and Muscle Mitochondrial Biogenesis and Exercise Tolerance.” American Journal of Physiology - Regulatory Integrative and Comparative Physiology. https://doi.org/10.1152/ajpregu.90925.2008.

_. 2009b. "Quercetin Increases Brain and Muscle Mitochondrial Biogenesis and Exercise Tolerance." American Journal of Physiology - Regulatory Integrative and Comparative Physiology. https://doi.org/10.1152/ajpregu.90925.2008.

Dimitrov, Nikolay V., Cheryl Meyer, Dennis Gilliland, Mary Ruppenthal, Wanda Chenoweth, and Winfred Malone. 1991. "Plasma Tocopherol Concentrations in 
Response to Supplemental Vitamin E." American Journal of Clinical Nutrition. https://doi.org/10.1093/ajcn/53.3.723.

Dolinsky, Vernon W, Kelvin E Jones, Robinder S Sidhu, Mark Haykowsky, Michael P Czubryt, Tessa Gordon, and Jason R B Dyck. 2012. "Improvements in Skeletal Muscle Strength and Cardiac Function Induced by Resveratrol during Exercise Training Contribute to Enhanced Exercise Performance in Rats." The Journal of Physiology 590 (11): 2783-99. https://doi.org/10.1113/jphysiol.2012.230490.

Doma, Kenji, Daniel Gahreman, and Jonathan Connor. 2020. "Fruit Supplementation Reduces Indices of Exercise-Induced Muscle Damage: A Systematic Review and MetaAnalysis.” European Journal of Sport Science. https://doi.org/10.1080/17461391.2020.1775895.

Done, Aaron J, Matthew J Gage, Nathan C Nieto, and Tinna Traustadottir. 2016. "ExerciseInduced Nrf2-Signaling Is Impaired in Aging.” Free Radical Biology \& Medicine 96: 130-38. https://doi.org/https://dx.doi.org/10.1016/j.freeradbiomed.2016.04.024.

Forman, Henry J., Kelvin J.A. Davies, and Fulvio Ursini. 2014. "How Do Nutritional Antioxidants Really Work: Nucleophilic Tone and Para-Hormesis versus Free Radical Scavenging in Vivo.” Free Radical Biology and Medicine. https://doi.org/10.1016/j.freeradbiomed.2013.05.045.

Frank, Jan, Naomi K Fukagawa, Anna R Bilia, Elizabeth J Johnson, Oran Kwon, Vish Prakash, Teruo Miyazawa, et al. 2019. “Terms and Nomenclature Used for PlantDerived Components in Nutrition and Related Research: Efforts toward Harmonization.” Nutrition Reviews. https://doi.org/10.1093/nutrit/nuz081.

Gaamouri, Nawel, Hassane Zouhal, Mehrez Hammami, Anthony C Hackney, Abderraouf Ben Abderrahman, Ayoub Saeidi, Rawad El Hage, and Omar Ben Ounis. 2019. "Effects of Polyphenol (Carob) Supplementation on Body Composition and Aerobic Capacity in Taekwondo Athletes." Physiology \& Behavior 205 (June): 22-28. https://doi.org/10.1016/j.physbeh.2019.03.003.

Gander, Jennifer, Duck Chul Lee, Xuemei Sui, James R. Hébert, Steven P. Hooker, and Steven N. Blair. 2011. "Self-Rated Health Status and Cardiorespiratory Fi Tness as Predictors of Mortality in Men." British Journal of Sports Medicine. https://doi.org/10.1136/bjsm.2010.079855. 
Giolo, Jéssica S., Juliene G. Costa, Jair P. da Cunha-Junior, Ana Cláudia A.M. Pajuaba, Ernesto A. Taketomi, Adriele V. de Souza, Douglas C. Caixeta, et al. 2018. "The Effects of Isoflavone Supplementation plus Combined Exercise on Lipid Levels, and Inflammatory and Oxidative Stress Markers in Postmenopausal Women." Nutrients. https://doi.org/10.3390/nu10040424.

Gliemann, Lasse, Jakob Friis Schmidt, Jesper Olesen, Rasmus Sjørup Biensø, Sebastian Louis Peronard, Simon Udsen Grandjean, Stefan Peter Mortensen, et al. 2013. "Resveratrol Blunts the Positive Effects of Exercise Training on Cardiovascular Health in Aged Men." The Journal of Physiology 591 (20): 5047-59. https://doi.org/10.1113/jphysiol.2013.258061.

Gomez-Cabrera, Mari Carmen, Elena Domenech, Marco Romagnoli, Alessandro Arduini, Consuelo Borras, Federico V. Pallardo, Juan Sastre, and Jose Viña. 2008. "Oral Administration of Vitamin C Decreases Muscle Mitochondrial Biogenesis and Hampers Training-Induced Adaptations in Endurance Performance.” American Journal of Clinical Nutrition. https://doi.org/10.1093/ajen/87.1.142.

Gomez-Cabrera, Mari Carmen, Beatriz Ferrando, Thomas Brioche, Fabian Sanchis-Gomar, and Jose Viña. 2013. "Exercise and Antioxidant Supplements in the Elderly." Journal of Sport and Health Science. https://doi.org/10.1016/j.jshs.2013.03.007.

Guerrieri, Davide, Hyo Youl Moon, and Henriette van Praag. 2017. "Exercise in a Pill: The Latest on Exercise-Mimetics.” Brain Plasticity. https://doi.org/10.3233/bpl-160043.

Habauzit, Vèronique, and Christine Morand. 2012. "Evidence for a Protective Effect of Polyphenols-Containing Foods on Cardiovascular Health: An Update for Clinicians.” Therapeutic Advances in Chronic Disease. https://doi.org/10.1177/2040622311430006.

Halliwell, Barry. 2008. "Are Polyphenols Antioxidants or Pro-Oxidants? What Do We Learn from Cell Culture and in Vivo Studies?" Archives of Biochemistry and Biophysics. https://doi.org/10.1016/j.abb.2008.01.028.

Hart, Nikolett, Linda Sarga, Zsolt Csende, Erika Koltai, Lauren G. Koch, Steven L. Britton, Kelvin J.A. Davies, Dimitris Kouretas, Barbara Wessner, and Zsolt Radak. 2013. "Resveratrol Enhances Exercise Training Responses in Rats Selectively Bred for High Running Performance." Food and Chemical Toxicology. https://doi.org/10.1016/j.fct.2013.01.051. 
Higgins JPT, Thomas J, Chandler J, Cumpston M, Li T, Page MJ, Welch VA. 2019.

“Cochrane Handbook for Systematic Reviews of Interventions Version 6.0 (Updated July 2019). Cochrane, 2019." Handbook.

Higgins JPT, Green S (editors). 2011. "Cochrane Handbook for Systematic Reviews of Interventions Version 5.1.0 .” The Cochrane Collaboration . 2011.

Higgins, Julian P.T., Simon G. Thompson, Jonathan J. Deeks, and Douglas G. Altman. 2003. "Measuring Inconsistency in Meta-Analyses." British Medical Journal. https://doi.org/10.1136/bmj.327.7414.557.

Hill, Alison M, Alison M Coates, Jonathan D Buckley, Robert Ross, Frank Thielecke, and Peter R C Howe. 2007. "Can EGCG Reduce Abdominal Fat in Obese Subjects?” Journal of the American College of Nutrition 26 (4): 396S-402S. http://search.ebscohost.com/login.aspx?direct=true \&db=cmedm\&AN=17906193\&site= ehost-live.

Hollman, Peter C. H., Aedin Cassidy, Blandine Comte, Marina Heinonen, Myriam Richelle, Elke Richling, Mauro Serafini, Augustin Scalbert, Helmut Sies, and Stéphane Vidry. 2011. "The Biological Relevance of Direct Antioxidant Effects of Polyphenols for Cardiovascular Health in Humans Is Not Established." The Journal of Nutrition. https://doi.org/10.3945/jn.110.131490.

Ichinose, T, S Nomura, Y Someya, S Akimoto, K Tachiyashiki, and K Imaizumi. 2011. "Effect of Endurance Training Supplemented with Green Tea Extract on Substrate Metabolism during Exercise in Humans." Scandinavian Journal of Medicine \& Science in Sports 21 (4): 598-605. $\mathrm{http}: / /$ search.ebscohost.com/login.aspx?direct=true $\& \mathrm{db}=\mathrm{s} 3 \mathrm{~h} \& \mathrm{AN}=62836783 \&$ site $=$ ehos t-live.

Kim, Hunkyung, Takao Suzuki, Kyoko Saito, Hideyo Yoshida, Narumi Kojima, Miji Kim, Motoki Sudo, Yukari Yamashiro, and Ichiro Tokimitsu. 2013. "Effects of Exercise and Tea Catechins on Muscle Mass, Strength and Walking Ability in Community-Dwelling Elderly Japanese Sarcopenic Women: A Randomized Controlled Trial.” Geriatrics \& Gerontology International 13 (2): 458-65. https://doi.org/10.1111/j.14470594.2012.00923.x.

Knekt, Paul, Jorma Kumpulainen, Ritva Järvinen, Harri Rissanen, Markku Heliövaara, Antti 

Reunanen, Timo Hakulinen, and Arpo Aromaa. 2002. "Flavonoid Intake and Risk of Chronic Diseases.” American Journal of Clinical Nutrition. https://doi.org/10.1093/ajen/76.3.560.

Kuo, Yu-Chi, Jung-Charng Lin, Jeffrey R Bernard, and Yi-Hung Liao. 2015. "Green Tea Extract Supplementation Does Not Hamper Endurance-Training Adaptation but Improves Antioxidant Capacity in Sedentary Men." Applied Physiology, Nutrition \& Metabolism 40 (10): 990-96. http://search.ebscohost.com/login.aspx?direct=true \&db=s3h\&AN=110081474\&site=eho st-live.

Lagouge, Marie, Carmen Argmann, Zachary Gerhart-Hines, Hamid Meziane, Carles Lerin, Frederic Daussin, Nadia Messadeq, et al. 2006. "Resveratrol Improves Mitochondrial Function and Protects against Metabolic Disease by Activating SIRT1 and PGC-1 $\alpha . ”$ Cell. https://doi.org/10.1016/j.cell.2006.11.013.

Layne, Andrew S, Lisa M Krehbiel, Robert T Mankowski, Stephen D Anton, Christiaan Leeuwenburgh, Marco Pahor, Bhanuprasad Sandesara, Samuel S Wu, and Thomas W Buford. 2017. "Resveratrol and Exercise to Treat Functional Limitations in Late Life: Design of a Randomized Controlled Trial." Contemporary Clinical Trials Communications 6 (June): 58-63. https://doi.org/10.1016/j.conctc.2017.03.002.

Lebon, Johann, Eleonor Riesco, Daniel Tessier, and Isabelle J Dionne. 2014. “Additive Effects of Isoflavones and Exercise Training on Inflammatory Cytokines and Body Composition in Overweight and Obese Postmenopausal Women: A Randomized Controlled Trial." Menopause (New York, N.Y.) 21 (8): 869-75. https://doi.org/10.1097/GME.0000000000000177.

Lemmer, J. T., D. E. Hurlbut, G. F. Martel, B. L. Tracy, F. M. Ivey, E. J. Metter, J. L. Fozard, J. L. Fleg, and B. F. Hurley. 2000. “Age and Gender Responses to Strength Training and Detraining." Medicine and Science in Sports and Exercise. https://doi.org/10.1097/00005768-200008000-00021.

Lin, Jen Kun, and Shoei Yn Lin-Shiau. 2006a. "Mechanisms of Hypolipidemic and AntiObesity Effects of Tea and Tea Polyphenols.” Molecular Nutrition and Food Research. https://doi.org/10.1002/mnfr.200500138.

—. 2006b. "Mechanisms of Hypolipidemic and Anti-Obesity Effects of Tea and Tea 
Polyphenols." Molecular Nutrition and Food Research. https://doi.org/10.1002/mnfr.200500138.

López-López, José A., Matthew J. Page, Mark W. Lipsey, and Julian P.T. Higgins. 2018. "Dealing with Effect Size Multiplicity in Systematic Reviews and Meta-Analyses." Research Synthesis Methods. https://doi.org/10.1002/jrsm.1310.

Mafi, Farnoosh, Soheil Biglari, Alireza Ghardashi Afousi, and Abbas Ali Gaeini. 2019. "Improvement in Skeletal Muscle Strength and Plasma Levels of Follistatin and Myostatin Induced by an 8-Week Resistance Training and Epicatechin Supplementation in Sarcopenic Older Adults.” Journal of Aging \& Physical Activity 27 (3): 384-91. http://search.ebscohost.com/login.aspx?direct=true $\& \mathrm{db}=\mathrm{s} 3 \mathrm{~h} \& \mathrm{AN}=136543369 \&$ site $=$ eho st-live.

Manach, Claudine, Gary Williamson, Christine Morand, Augustin Scalbert, and Christian Rémésy. 2005. "Bioavailability and Bioefficacy of Polyphenols in Humans. I. Review of 97 Bioavailability Studies.” The American Journal of Clinical Nutrition. https://doi.org/10.1093/ajen/81.1.230s.

Margaritelis, Nikos V., Vassilis Paschalis, Anastasios A. Theodorou, Antonios Kyparos, and Michalis G. Nikolaidis. 2020. “Antioxidant Supplementation, Redox Deficiencies and Exercise Performance: A Falsification Design.” Free Radical Biology and Medicine. https://doi.org/10.1016/j.freeradbiomed.2020.06.029.

Mi, Yashi, Wentong Zhang, Haoyu Tian, Runnan Li, Shuxian Huang, Xingyu Li, Guoyuan Qi, and Xuebo Liu. 2018. "EGCG Evokes Nrf2 Nuclear Translocation and Dampens PTP1B Expression to Ameliorate Metabolic Misalignment under Insulin Resistance Condition." Food \& Function 9 (3): 1510-23. https://doi.org/https://dx.doi.org/10.1039/c7fo01554b.

Moher, David, Alessandro Liberati, Jennifer Tetzlaff, Douglas G. Altman, Doug Altman, Gerd Antes, David Atkins, et al. 2009. "Preferred Reporting Items for Systematic Reviews and Meta-Analyses: The PRISMA Statement." PLoS Medicine. https://doi.org/10.1371/journal.pmed.1000097.

Momken, Iman, Laurence Stevens, Audrey Bergouignan, Dominique Desplanches, Floriane Rudwill, Isabelle Chery, Alexandre Zahariev, et al. 2011. "Resveratrol Prevents the Wasting Disorders of Mechanical Unloading by Acting as a Physical Exercise Mimetic 
in the Rat.” The FASEB Journal. https://doi.org/10.1096/fj.10-177295.

Morgan, Paul T., Matthew J. Barton, and Joanna L. Bowtell. 2019. "Montmorency Cherry Supplementation Improves 15-Km Cycling Time-Trial Performance.” European Journal of Applied Physiology. https://doi.org/10.1007/s00421-018-04058-6.

Myburgh, Kathryn H. 2014. "Polyphenol Supplementation: Benefits for Exercise Performance or Oxidative Stress?” Sports Medicine. https://doi.org/10.1007/s40279014-0151-4.

Orsatti, Fábio Lera, Eliana Aguiar Petri Nahas, Jorge Nahas-Neto, Nailza Maesta, Cláudio Lera Orsatti, and Cesar Edurado Fernandes. 2010. "Effects of Resistance Training and Soy Isoflavone on Body Composition in Postmenopausal Women." Obstetrics and Gynecology International 2010: 156037. https://doi.org/10.1155/2010/156037.

Pandey, Kanti Bhooshan, and Syed Ibrahim Rizvi. 2009. "Plant Polyphenols as Dietary Antioxidants in Human Health and Disease." Oxidative Medicine and Cellular Longevity. https://doi.org/10.4161/oxim.2.5.9498.

Paulsen, G., H. Hamarsland, K. T. Cumming, R. E. Johansen, J. J. Hulmi, E. Børsheim, H. Wiig, I. Garthe, and T. Raastad. 2014. "Vitamin C and E Supplementation Alters Protein Signalling after a Strength Training Session, but Not Muscle Growth during 10 Weeks of Training." Journal of Physiology. https://doi.org/10.1113/jphysiol.2014.279950.

Paulsen, Gøran, Kristoffer T. Cumming, Geir Holden, Jostein Hallén, Bent Ronny Rønnestad, Ole Sveen, Arne Skaug, et al. 2014. "Vitamin C and E Supplementation Hampers Cellular Adaptation to Endurance Training in Humans: A Double-Blind, Randomised, Controlled Trial.” Journal of Physiology. https://doi.org/10.1113/jphysiol.2013.267419.

Rice-Evans, Catherine A., Nicholas J. Miller, and George Paganga. 1997. "Antioxidant Properties of Phenolic Compounds." Trends in Plant Science. https://doi.org/10.1016/S1360-1385(97)01018-2.

Rio, Daniele Del, Ana Rodriguez-Mateos, Jeremy P.E. Spencer, Massimiliano Tognolini, Gina Borges, and Alan Crozier. 2013. "Dietary (Poly)Phenolics in Human Health: Structures, Bioavailability, and Evidence of Protective Effects against Chronic Diseases." Antioxidants and Redox Signaling. https://doi.org/10.1089/ars.2012.4581. 
Consumption Does Not Impair Training-Induced Improvements in Exercise Performance." International Journal of Sports Physiology and Performance. https://doi.org/10.1123/ijspp.6.1.58.

Sadowska-Krępa, Ewa, Przemysław Domaszewski, Ilona Pokora, Aleksandra Żebrowska, Agnieszka Gdańska, and Tomasz Podgórski. 2019. "Effects of Medium-Term Green Tea Extract Supplementation Combined with CrossFit Workout on Blood Antioxidant Status and Serum Brain-Derived Neurotrophic Factor in Young Men: A Pilot Study.” Journal of the International Society of Sports Nutrition 16 (1): N.PAG-N.PAG. http://search.ebscohost.com/login.aspx?direct=true \&db=s3h\&AN=135468033\&site=eho st-live.

Sahin, Kazim, Ragip Pala, Mehmet Tuzcu, Oguzhan Ozdemir, Cemal Orhan, Nurhan Sahin, and Vijaya Juturu. 2016. "Curcumin Prevents Muscle Damage by Regulating NF-KB and Nrf2 Pathways and Improves Performance: An in Vivo Model." Journal of Inflammation Research. https://doi.org/10.2147/JIR.S110873.

Sandoval-Acuña, Cristian, Jorge Ferreira, and Hernán Speisky. 2014. "Polyphenols and Mitochondria: An Update on Their Increasingly Emerging ROS-Scavenging Independent Actions." Archives of Biochemistry and Biophysics. https://doi.org/10.1016/j.abb.2014.05.017.

Santos, Tanila Wood Dos, Quélita Cristina Pereira, Lucimara Teixeira, Alessandra Gambero, Josep A. Villena, and Marcelo Lima Ribeiro. 2018. "Effects of Polyphenols on Thermogenesis and Mitochondrial Biogenesis." International Journal of Molecular Sciences. https://doi.org/10.3390/ijms19092757.

Scalbert, Augustin, Ian T. Johnson, and Mike Saltmarsh. 2005. "Polyphenols: Antioxidants and Beyond." The American Journal of Clinical Nutrition. https://doi.org/10.1093/ajcn/81.1.215s.

Scalbert, Augustin, Christine Morand, Claudine Manach, and Christian Rémésy. 2002. "Absorption and Metabolism of Polyphenols in the Gut and Impact on Health." Biomedicine and Pharmacotherapy. https://doi.org/10.1016/S0753-3322(02)00205-6.

Schwarz, Neil A., Zachary J. Blahnik, Srihari Prahadeeswaran, Sarah K. McKinley-Barnard, Shelley L. Holden, and Andy Waldhelm. 2018. “(-)-Epicatechin Supplementation Inhibits Aerobic Adaptations to Cycling Exercise in Humans." Frontiers in Nutrition. 
https://doi.org/10.3389/fnut.2018.00132.

Scribbans, Trisha D, Jasmin K Ma, Brittany A Edgett, Kira A Vorobej, Andrew S Mitchell, Jason G E Zelt, Craig A Simpson, Joe Quadrilatero, and Brendon J Gurd. 2014. "Resveratrol Supplementation Does Not Augment Performance Adaptations or FibreType-Specific Responses to High-Intensity Interval Training in Humans.” Applied Physiology, Nutrition \& Metabolism 39 (11): 1305-13. http://search.ebscohost.com/login.aspx?direct=true \&db=s3h\&AN=99044759\&site=ehos t-live.

Shafiee, Gita, Abbasali Keshtkar, Akbar Soltani, Zeinab Ahadi, Bagher Larijani, and Ramin Heshmat. 2017. "Prevalence of Sarcopenia in the World: A Systematic Review and Meta- Analysis of General Population Studies." Journal of Diabetes and Metabolic Disorders. https://doi.org/10.1186/s40200-017-0302-x.

Somerville, Vaughan, Cameron Bringans, and Andrea Braakhuis. 2017. "Polyphenols and Performance: A Systematic Review and Meta-Analysis.” Sports Medicine. https://doi.org/10.1007/s40279-017-0675-5.

Sui, Xuemei, Michael J. LaMonte, James N. Laditka, James W. Hardin, Nancy Chase, Steven P. Hooker, and Steven N. Blair. 2007. "Cardiorespiratory Fitness and Adiposity as Mortality Predictors in Older Adults." Journal of the American Medical Association. https://doi.org/10.1001/jama.298.21.2507.

Thompson, Christopher, Anni Vanhatalo, Stefan Kadach, Lee J. Wylie, Jonathan Fulford, Scott K. Ferguson, Jamie R. Blackwell, Stephen J. Bailey, and Andrew M. Jones. 2018. "Discrete Physiological Effects of Beetroot Juice and Potassium Nitrate Supplementation Following 4-Wk Sprint Interval Training.” Journal of Applied Physiology. https://doi.org/10.1152/japplphysiol.00047.2018.

Trappe, Todd A., Chad C. Carroll, Jared M. Dickinson, Jennifer K. LeMoine, Jacob M. Haus, Bridget E. Sullivan, Jonah D. Lee, Bozena Jemiolo, Eileen M. Weinheimer, and Chris J. Hollon. 2011. "Influence of Acetaminophen and Ibuprofen on Skeletal Muscle Adaptations to Resistance Exercise in Older Adults." American Journal of Physiology Regulatory Integrative and Comparative Physiology. https://doi.org/10.1152/ajpregu.00611.2010.

Trappe, Todd A., Stephen M. Ratchford, Brooke E. Brower, Sophia Z. Liu, Kaleen M. Lavin, 
Chad C. Carroll, Bozena Jemiolo, and Scott W. Trappe. 2016. "COX Inhibitor Influence on Skeletal Muscle Fiber Size and Metabolic Adaptations to Resistance Exercise in Older Adults.” Journals of Gerontology - Series A Biological Sciences and Medical Sciences. https://doi.org/10.1093/gerona/glv231.

Trexler, Eric T., Abbie E. Smith-Ryan, Malia N. Melvin, Erica J. Roelofs, and Hailee L. Wingfield. 2014. "Effects of Pomegranate Extract on Blood Flow and Running Time to Exhaustion." Applied Physiology, Nutrition and Metabolism. https://doi.org/10.1139/apnm-2014-0137.

Ursini, Fulvio, Matilde Maiorino, and Henry Jay Forman. 2016. "Redox Homeostasis: The Golden Mean of Healthy Living." Redox Biology. https://doi.org/10.1016/j.redox.2016.01.010.

Wedick, Nicole M., An Pan, Aedín Cassidy, Eric B. Rimm, Laura Sampson, Bernard Rosner, Walter Willett, Frank B. Hu, Qi Sun, and Rob M. Van Dam. 2012. "Dietary Flavonoid Intakes and Risk of Type 2 Diabetes in US Men and Women." American Journal of Clinical Nutrition. https://doi.org/10.3945/ajcn.111.028894.

Wiswedel, Ingrid, Daniela Hirsch, Siegfried Kropf, Martin Gruening, Eberhard Pfister, Tankred Schewe, and Helmut Sies. 2004. "Flavanol-Rich Cocoa Drink Lowers Plasma F2-Isoprostane Concentrations in Humans." Free Radical Biology and Medicine. https://doi.org/10.1016/j.freeradbiomed.2004.05.013.

Wu, Jian, Jun Oka, Mitsuru Higuchi, Izumi Tabata, Toshiya Toda, Maiko Fujioka, Noriyuki Fuku, et al. 2006. "Cooperative Effects of Isoflavones and Exercise on Bone and Lipid Metabolism in Postmenopausal Japanese Women: A Randomized Placebo-Controlled Trial." Metabolism: Clinical and Experimental 55 (4): 423-33.

http://search.ebscohost.com/login.aspx?direct=true \&db=cmedm\&AN=16546471\&site= ehost-live.

Wu, Jian, Jun Oka, Izumi Tabata, Mitsuru Higuchi, Toshiya Toda, Noriyuki Fuku, Junko Ezaki, et al. 2006. "Effects of Isoflavone and Exercise on BMD and Fat Mass in Postmenopausal Japanese Women: A 1-Year Randomized Placebo-Controlled Trial.” Journal of Bone and Mineral Research: The Official Journal of the American Society for Bone and Mineral Research 21 (5): 780-89. http://search.ebscohost.com/login.aspx .direct=true $\& \mathrm{db}=\mathrm{cmedm} \& \mathrm{AN}=16734394 \&$ site= 
ehost-live.

372 Yfanti, Christina, Anders R. Nielsen, Thorbjörn Åkerström, Soren Nielsen, Adam J. Rose, 373 Erik A. Richter, Jens Lykkesfeldt, Christian P. Fischer, and Bente K. Pedersen. 2011. 374 "Effect of Antioxidant Supplementation on Insulin Sensitivity in Response to Endurance 375 Exercise Training." American Journal of Physiology - Endocrinology and Metabolism. https://doi.org/10.1152/ajpendo.00207.2010.

377

378

379 